\title{
ANTECIPAÇÃO DOS EFEITOS DA TUTELA NOS PROCESSOS DE APOSENTADORIA ESPECIAL À LUZ DO PRINCÍPIO DA DIGNIDADE DA PESSOA HUMANA
}

\section{ANTICIPATION OF THE EFFECTS OF TUTELING ON SPECIAL RETIREMENT PROCESSES IN THE LIGHT OF THE HUMAN PERSON'S DIGNITY PRINCIPLE}

\author{
Mila Christian Batista de Pádua* \\ Wilba Lúcia Maia Bernardes**
}

\begin{abstract}
RESUMO
Este trabalho tem por objetivo o desenvolvimento por meio de pesquisa bibliográfica e jurisprudencial, de caráter quantitativo e por procedimento dedutivo, analisar o Instituto das Tutelas de Urgência e da apreciação judicial, como um meio processual capaz de garantir a eficácia dos Direitos Fundamentais, no tocante aos casos de Aposentadoria Especial. Neste contexto, o Instituto das Tutelas de Urgência, seja ela concedida em primeiro grau de jurisdição ou em sede recursal, é capaz de atenuar a morosidade jurisdicional e em consequência possibilita ao processo constitucional a aplicação do princípio da celeridade, visando dar ao segurado a garantia de seus Direitos Fundamentais, em especial, o Princípio da Dignidade da Pessoa Humana, assegurando o caráter alimentar do benefício previdenciário casos decididos pelos nossos Tribunais.
\end{abstract}

Palavras-chave: Princípio da Dignidade da Pessoa Humana. Tutelas de Urgência. Aposentadoria Especial. Conversão do Tempo Especial. Violação a Princípios Constitucionais.

\begin{abstract}
This work aims to develop means of bibliographic and jurisprudential research, of a quantitative nature and by deductive procedure, from the analysis for Emergency Guardianship and Judicial Review, as a process capable of guaranteeing the use of Fundamental Rights, about Special Retirement Cases. In this context, the Urgency Guardianship Institute, whether granted in the first degree of jurisdiction or at the appellate court, can mitigate the length of jurisdiction and the consequent possibility of a constitutional process for applying the principle of speed and providing security to the guarantee. In its Fundamental Rights, in particular, the Principle of the Dignity of Human Beings, ensuring the alimentary character of the benefit precedent cases determined by our Courts.
\end{abstract}

Keywords: Principle of Human Dignity.Emergency Guardianship. Special Retirement. Special Time Conversion. Violation of Constitutional Principles.

Artigo submetido em 18 de novembro de 2020 e aprovado em 17 de março de 2021.

* Graduanda em Direito pela Faculdade Mineira de Direito da Pontifícia Universidade Católica de Minas Gerais. E-mail:

** Doutora em Direito Constitucional pela Universidade Federal de Minas Gerais; Mestrado em Direito Constitucional pela Universidade Federal de Minas Gerais; Graduação em Direito pela Faculdade de Direito Milton Campos. E-mail: wilba@pucminas.br 


\section{INTRODUÇÃO}

O trabalho em questão busca analisar o Instituto das Tutelas de Urgência e a atuação dos Juízes Federais, visando a efetivação do Princípio da Dignidade da Pessoa Humana e sua garantia e, consequentemente, estabelecer o caráter alimentar do benefício concedido ao segurado.

Nesse sentido, surge o questionamento: A tutela antecipada nos processos de aposentadoria especial seria um instrumento processual capaz de garantir à efetividade do princípio da dignidade da pessoa humana?

Nessa perspectiva, a necessidade do pedido de tutela antecipada, também visa dar eficiência e celeridade não só a atividade jurisdicional como também ao processo constitucional, uma vez que o poder judiciário enfrenta um grande problema, como a morosidade.

A utilização deste instrumento processual possibilita a aplicação dos princípios da celeridade processual e duração razoável do processo nos termos do art $5^{\circ}$, LXXVIII - a todos, no âmbito judicial e administrativo, são assegurados a razoável duração do processo e os meios que garantam a celeridade de sua tramitação.CR/88, de suma importância para o processo constitucional.

Na tutela de recursal de urgência, busca-se antecipar os efeitos de uma futura decisão, concretizando a pretensão daquele que se socorre do judiciário amenizando os efeitos da morosidade processual e dividindo os ônus do tempo do processo, de modo que o jurisdicionado possa obter com o processo um resultado útil. (FRANZÉ, CALIL e FRANÇOSO, pág. 3, 2018, [PDF]).

Em se tratando de aposentadoria especial, ou seja, um direito fundamental, o que é garantido ao trabalhador submetido ao exercício da atividade laboral exposto a agentes nocivos, em especial o agente "ruído", grande causador de prejuízos à saúde e à integridade física.

Ademais, ao verificar que a demora na análise dos processos, pode gerar prejuízos à saúde do segurado, tendo em vista que ele possui capacidade para o exercício da atividade laboral reduzida, seja em razão da sua idade ou, em razão de estar com a saúde comprometida, pelo fato de trabalhar em ambiente degradante, mesmo com a utilização de Equipamento de Proteção Individual (EPI).

A hipótese apresentada busca analisar o instituto da tutela de urgência como instrumento capaz de garantir o princípio da dignidade da pessoa humana quanto ao caráter alimentar do benefício previdenciário, e "a posteriori”, estudar a atuação dos Juízes Federais, com relação à atuação processual para concessão das aposentadorias especiais quando as tutelas de urgência não são eficazes. Analisar em especial a causa concreta nos processos de Aposentadoria Especial, no que diz respeito ao agente nocivo, em especial os "agentes físicos", em conformidade o entendimento jurisprudencial do Supremo Tribunal Federal (STF).

A relevância deste tema decorre da morosidade do sistema judiciário atual, relativamente aos processos, em que, o segurado passou grande parte de sua vida exposto a algum tipo de agente prejudicial à sua saúde ou à sua integridade física. Deste modo que a tutela de urgência é um instrumento processual capaz a agilizar o processo, tanto no momento da sentença quanto em sede recursal, tornando-o mais justo ao segurado, o qual se encontra em posição desvantagem na relação jurídica, tendo em vista que seu benefício foi negado administrativamente. Nesse sentido, a concessão de tal instrumento torna-se eficiente ao ponto de garantir a todos os segurados seus direitos fundamentais.

\section{FUNDAMENTAÇÃO CONSTITUCIONAL}


Artigo: Antecipação dos efeitos da tutela nos processos de aposentadoria especial à luz do princípio da dignidade da pessoa humana

No decorrer da história a doutrina discute sobre direitos fundamentais, em especial, o que seria o Princípio da Dignidade da Pessoa Humana.

$\mathrm{Na}$ visão de Luís Roberto Barroso é: “[...] um valor intrínseco de cada pessoa e a capacidade individual de ter acesso a razão, de fazer escolhas morais e determinar seu próprio destino[...]" (BARROSO, 2016, pág. 61), quando se trata do ponto de vista da moralidade. De fato, após a segunda guerra o conceito de dignidade da pessoa humana, não só se tornou um discurso político como também foi empregado em constituições, bem como em vários tratados pelo mundo, a fim de ser este princípio alcançado pelas instituições nacionais ou internacionais.

Surge então o dever do Estado de garantir as necessidades vitais de cada indivíduo, porém, não basta assegurar direitos para a humanidade como um todo é necessário olhar um a um, pois existe um valor intrínseco em cada pessoa. A cada vez mais tem-se falado sobre o princípio da dignidade da pessoa humana, por ser um princípio muito amplo e flexível, ele funciona como um espelho, em que cada indivíduo projeta seus valores. Nesse sentido, a flexibilidade deste princípio compromete a capacidade de resolução das controvérsias, assim, compreende-se interpretações mais divergentes, e ainda, há que se destacar que não é dado o devido valor a este fundamento constitucional ou pior ao se banalizar o princípio ele passa a ser usado como discurso por alguns juízes, desembargadores, legisladores e governadores dentre outros, que apoiam teses opressoras e injustas, Contudo, devemos evidenciar a importância deste princípio, pois é um sinal de avanço, afinal se trata de um princípio que busca a garantia dos direitos mais básicos, mas deve ser ele analisado com maior profundidade, dado que é uma ferramenta de luta para condições decentes de vida.

No texto constitucional a dignidade da pessoa humana é uma norma e ocupa uma posição especial, ou seja, consiste em um dos fundamentos do nosso país, apesar de ela não estar incluída no rol dos direitos e garantias fundamentais, a norma prevista no artigo $1^{\circ}$, inciso III da Constituição da República se encontra em posição de princípio fundamental, in verbis:

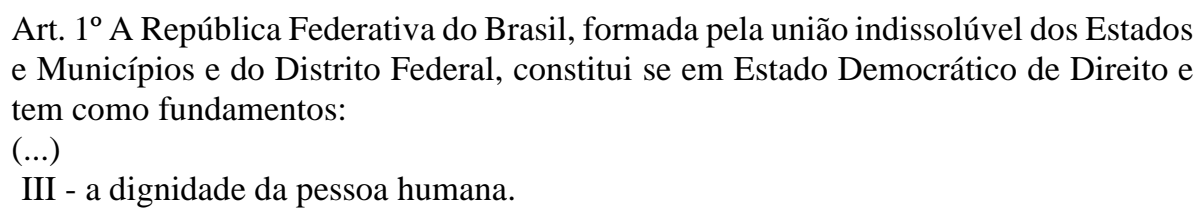

Dessa forma, a Constituição da República atribui aos princípios fundamentais orientar toda a ordem constitucional.

Nessa perspectiva, a dignidade da pessoa humana, ganhou enorme dimensão após a segunda guerra, razão pela qual tornou-se um conceito jurídico, no sentido de que os indivíduos de toda a sociedade sofrem a todo momento ofensas e violações aos mais diversos direitos basilares.

Assim, Gilmar Mendes, definiu os direitos fundamentais como:

O catálogo dos direitos fundamentais na Constituição consagra liberdades variadas e procura garanti-las por meio de diversas normas. Liberdade e igualdade formam dois elementos essenciais do conceito de dignidade da pessoa humana, que o constituinte erigiu à condição de fundamento do Estado Democrático de Direito e vértice do sistema dos direitos fundamentais. (MENDES 2009, pág. 402).

No mesmo sentido, entende Jorge Mancini que partilha da mesma ideia relacionada aos direitos fundamentais:

Los derechos fundamentales serían aquellos derechos humanos que los ordenamientos jurídicos nacionales e internacionales han reconocido como indispensables y que necesariamente deben estar expresados en los documentos básicos y superiores, sin: 
que ello implique agotar la lista de los que componen el conjunto de derechos esenciales a la persona humana. (MANCINI 2004, pág. 10).

Sob o prisma dos Direitos Fundamentais e da importância desses para o Direito Previdenciário, especificamente quando se trata da aposentadoria especial e o seu novo tratamento após a Emenda Constitucional (EC) no 103/2019. Aqui também devem ser analisados as tutelas de urgência como instrumento processual capaz de satisfazer e garantir ao segurado seus direitos.

Primeiramente, definimos a natureza da aposentadoria especial, sendo ela destinada a prevenção para assegurar a proteção do trabalhador que se expõe efetivamente de agentes agressivos prejudiciais à saúde e à integridade física. Sendo uma espécie do gênero de aposentadoria por tempo de contribuição:

No mesmo sentido, Denilson Almeida Pereira, afirma que a aposentadoria especial tem como sua finalidade: "[...]impedir que o trabalhador venha a sofrer prejuizos a sua saúde ou integridade física em decorrência da exposição ao agente nocivo por tempo superior ao suportável[...]" (Pereira,2011, pág.8).

Carlos Alberto Pereira de Castro e João Batista Lazzari sobre a matéria atribuem a natureza e a finalidade de:

[...] A aposentadoria especial é uma espécie de aposentadoria por tempo de contribuição, com redução do tempo necessário à inativação, concedida (segundo o art. 201, § $1^{\circ}$, da Constituição - redação anterior à EC n. 103/2019) em razão do exercício de atividades consideradas prejudiciais à saúde ou à integridade física (...) reparar financeiramente o trabalhador sujeito a condições de trabalho inadequadas[...]. (Castro e Lazzari, 2019, pág. 1023).

Diversamente, Fábio Zambite Ibrahim define a natureza do benefício de Aposentadoria Especial como, uma espécie do gênero de aposentadoria por Invalidez: “[...]este benefício seria uma espécie de aposentadoria por invalidez antecipada, na medida em que proporciona a aposentação antes do segurado ser efetivamente incapacitado pelos agentes nocivos a que está exposto". (IBRAHIM, 2008. p. 552).

Desta maneira, a natureza do benefício da aposentadoria especial é espécie do gênero aposentadoria por tempo de contribuição, não podendo ser considerada o gênero invalidez pelo fato de o segurado ficar efetivamente incapacitado, ainda em relação a reparação financeira que o trabalhador submetido a estas condições possui, tendo em vista que o benefício de aposentadoria especial possui o caráter preventivo.

A finalidade deste benefício atende ao fundamento constitucional e o princípio da dignidade da pessoa humana previsto na Constituição da República, em seu art. $1^{\circ}$, inciso III. Nesse sentido, quando se fala de justiça, sua função principal é tutelar os direitos, considerando o acesso à ordem jurídica justa e eficaz, à busca pela efetividade processual, no Estado Democrático de Direito.

A principal característica da atividade jurisdicional é tutelar o direito daquele que se acha em posição de desvantagem, no conflito conforme dispõe o "artigo $5^{\circ}$, inciso XXXV - a lei não excluirá da apreciação do Poder Judiciário lesão ou ameaça a direito".

Porém, há situações em que o segurado, ora trabalhador, enfrenta quando está diante do processo, a espera da composição do conflito pode gerar prejuízos ou risco para uma das partes, podendo assumir proporções graves, e comprometer a efetividade da tutela jurisdicional, em relação ao tempo de espera.

Considerando a morosidade nos trâmites processuais, o texto constitucional consagrou também no "artigo $5^{\circ}$, inciso LXXVIII - a todos, no âmbito judicial e administrativo, são assegurados a razoável duração do processo e os meios que garantam a celeridade de sua 
Artigo: Antecipação dos efeitos da tutela nos processos de aposentadoria especial à luz do princípio da dignidade da pessoa humana

tramitação", então criou-se técnicas para reduzir a duração do processo, essa medida cautelar denominadas tutelas de urgências, podendo ter o seu resultado provisório ou definitivo.

\title{
3 TUTELA DE URGÊNCIA
}

As tutelas de urgência possuem a função de proteger provisoriamente situações jurídicas, as quais indicam a existência de um direito subjetivo, e ainda, este instrumento possibilita antecipar provisoriamente o resultado útil do direito material que é discutido em juízo.

Segundo Humberto Theodoro, as tutelas de urgência são técnicas processuais, a saber:

\begin{abstract}
Às tutelas provisórias têm em comum a meta de combater os riscos de injustiças ou de dano, derivados da espera, sempre longa, pelo desate final do conflito submetido à solução judicial. Representam provimentos imediatos que, de alguma forma, possam obviar ou minimizar os inconvenientes e suportados pela parte que se acha numa situação de vantagem aparente tutelada pela ordem jurídica material (fumus boni iuris). Sem embargo de dispor de meios de convencimento para evidenciar, de plano, a superioridade de seu posicionamento em torno do objetivo litigioso, o demandante, segundo o procedimento comum, teria de se privar de sua usufruição, ou teria de correr o risco de vê-lo perecer, durante o aguardo da finalização do curso normal do processo (periculum in mora). (JÚNIOR, 2017, pág. 615).
\end{abstract}

Para Ovídio Baptista, Teori Albino Zavaski e Carlos Alberto Alvaro de Oliveira. as tutelas de urgência serão postuladas mediante "[...]elementos que evidenciem a probabilidade do direito e o perigo de dano ou o risco ao resultado útil do processo [...]", conforme expresso no artigo, 300 do CPC, sob pena da impossibilidade de execução futura e violação de seus direitos fundamentais.

A fim de sanar a morosidade no poder judiciário em relação a concessão de benefícios previdenciário, em especial, quando se trata de aposentadoria especial. Humberto Theodoro, considerou as tutelas de urgência como uma técnica processual, pois o Direito Previdenciário lida diretamente com elementos essenciais e direitos indispensáveis a qualquer cidadão.

Nesse sentido, as tutelas de urgência funcionam como uma técnica processual para antecipar o mérito, tendo em vista a urgência, dado que há um desgaste por parte do trabalhador que foi submetido a agentes nocivos à saúde.

No âmbito das tutelas de urgência a mais utilizada nos processos de aposentadoria especial é a tutela provisória de urgência de natureza antecipada, seus requisitos são "probabilidade do direito" e "perigo de dano ou o risco ao resultado útil do processo". Esse procedimento presente no processo jurisdicional é instrumento do exercício da jurisdição e também é instrumento de garantias de direito.

O paradigma no Estado Democrático de Direito quanto ao processo jurisdicional, acerca da pretensão de legitimidade do direito de obter em tempo hábil a tutela de jurisdicional do Estado, sob a lógica argumentativa, é por meio deste discurso se constrói teses jurídicas:

[...] O processo terá se desenvolvido utilmente e até o provimento, e a jurisdição terá cumprido a sua finalidade, que é a de apreciar se houver ou não ameaça ou lesão a direito, nos termos do art. $5^{\circ}, \mathrm{XXXV}$, da Constituição da República brasileira. (OLIVEIRA, 2016, pág. 169).

O processo jurisdicional exerce um papel fundamental, pois visa garantir que a pretensão do segurado seja efetivada. Tendo em vista que nas ações previdenciárias, o tempo de espera do julgamento é maior, pois Tribunais Regionais Federais abarcam grandes regiões, como é o caso do TRF 1. 


\title{
3.1. Comparação com o CPC de 1973
}

O instituto das tutelas surgiu no Código de Processos Civil de 1939, com o advento do CPC de 1973, com redação dada pela Lei $n^{\circ}$ 8.952/94, foi instituído a possibilidade da antecipação da tutela jurisdicional, contudo, ela seria utilizada apenas em algumas hipóteses, in verbis:

Art. 273. O juiz poderá, a requerimento da parte, antecipar, total ou parcialmente, os efeitos da tutela pretendida no pedido inicial, desde que, existindo prova inequívoca, se convença da verossimilhança da alegação e: (Redação dada pela Lei $n^{\circ} 8.952$, de 13.12.1994).

Sua finalidade é a proteção do próprio direito material pleiteado em juízo, de forma provisória, até a decisão final, a fim de evitar prejuízos. Haviam duas espécies, a Tutela Cautelar e a Tutela Antecipada.

Segundo Cândido Rangel Dinamarco, reconheceu a semelhança entre as duas espécies de tutelas, ressaltou que há comunhão de objetivos, é mais significativa do que a diferença entre elas, afirma textualmente que "são duas categorias de um gênero só, o das medidas urgentes." (DINAMARCO, 2003, pág.36).

De acordo com Humberto Theodoro Jr., declara:

\begin{abstract}
As medidas cautelares no regime do Código revogado eram objeto de ação apartada do processo principal, embora tivessem seus efeitos atrelados ao destino deste (art. 796 e 800 do CPC/1973). Já as medidas satisfativas urgentes eram invocáveis sempre no bojo do próprio processo principal (art. 273 do CPC/1973), não dependendo, portanto, do manejo de ação distinta. Eram, assim, objeto de mero incidente do processo já em curso. (JÚNIOR, 2017, pág. 618).
\end{abstract}

A tutela cautelar possuía tratamento distinto, pois havia um Livro específico para sua normatização (Livro III - Do Processo Cautelar) e era um meio de prestar a tutela jurisdicional mediata, instrumentalmente e de caráter não satisfativo, ou seja, a tutela cautelar ela basicamente um processo autônomo e dentro de processo de conhecimento que se insere a tutela antecipada, sujeitando-se a requisitos mais rigorosos do que os requisitos exigidos nas medidas cautelares.

A partir do CPC de 2015, o instituto das tutelas de urgência, foi aprimorado e trouxe inovações, presente no Livro V - Tutelas Provisórias.

Quanto a nova sistemática apresentada pelo CPC/15 às tutelas cautelares e as tutelas antecipadas, produzem efeitos jurídicos diferentes, em relação a possibilidade de estabilização dos efeitos da tutela concedida. Nota-se que houve a junção dos institutos em um único gênero, sendo extinto o processo de tutela cautelar.

De acordo com a leitura do artigo 294 do Código de Processo Civil de 2015, observase que há distinção entre tutela de urgência em caráter cautelar e em caráter antecedente. $\mathrm{O}$ pressuposto para a concessão das tutelas fundar-se-á em: "elementos que evidenciem a probabilidade do direito e o perigo de dano ou o risco ao resultado útil do processo."

Nesse sentido, a tutela cautelar, a partir da efetivação da decisão prolatada pelo magistrado, ficará o autor obrigado a formular o pedido principal no prazo de 15 (quinze) dias, no mesmo processo em que apresentou o pedido de tutela cautelar, independentemente do adiantamento de novas custas processuais.

A segunda espécie a tutela provisória de caráter antecedente, que é o objeto do nosso estudo a respeito dos processos de aposentadoria especial. É anterior ao ajuizamento da ação principal no prazo de 30 (trinta) dias para a efetivação da medida urgente, caso seja procedente, 
Artigo: Antecipação dos efeitos da tutela nos processos de aposentadoria especial à luz do princípio da dignidade da pessoa humana

o autor será obrigado a aditar a petição inicial, para complementar o argumento que deu ensejo ao pedido de tutela.

Ainda assim, o Professor Humberto Theodoro Jr., afirma:

[...] o novo Código eliminou essa dualidade de regime processual. Tanto a tutela conservativa é tratada, em regra, como objeto de mero incidente processual, que pode ser suscitado na petição inicial ou em petição avulsa (art.294, parágrafo único, do NCPC). (JÚNIOR,2017, pág. 618).

Hodiernamente, o novo CPC unificou as medidas em conservativas e satisfativas, e foram submetidas a dois requisitos "fumus boni iuris" e "periculum in mora". Dessa forma, a tutela provisória de urgência de natureza antecipada tem como objetivo quebrar a sequência normal do processo e antecipar o mérito.

\subsection{Do caráter alimentar do dispositivo}

A tutela antecipada, no âmbito do Direito Previdenciário, surge como uma resposta à morosidade da concessão de benefícios. Ocorre que em muitos casos o tempo e os desgastes em relação a vida profissional agravam a situação e isso se contrapõe à previsão constitucional, a que nos referimos acima no artigo primeiro, o fundamento da dignidade da pessoa humana.

A espécie das tutelas de urgência mais utilizada no Direito Previdenciário, no que diz respeito aos processos de aposentadoria especial, é a tutela provisória de urgência de natureza antecipada.

Considerando os requisitos para que seja concedida a tutela de urgência, ainda há a possibilidade de não haver o provimento da decisão. Assim, vislumbra-se que no art. $300, \S 3^{\circ}$, o CPC vedou a concessão das tutelas de urgência quando "houver perigo de irreversibilidade da decisão", nesse sentido, verifica-se que é inviável a concessão da tutela de urgência, pois os efeitos produzidos por ela não poderão voltar ao "status quo" ao final do processo.

A Constituição da República consagrou em seu artigo $100, \S 1^{\circ}$ a natureza alimentar dos benefícios previdenciários. Portanto a irreversibilidade, é apenas um ponto da controvérsia em relação à tutela antecipada.

Art. 100. Os pagamentos devidos pelas Fazendas Públicas Federal, Estaduais, Distrital e Municipais, em virtude de sentença judiciária, far-se-ão exclusivamente na ordem cronológica de apresentação dos precatórios e à conta dos créditos respectivos, proibida a designação de casos ou de pessoas nas dotações orçamentárias e nos créditos adicionais abertos para este fim. $\S 1^{\circ}$ Os débitos de natureza alimentícia compreendem aqueles decorrentes de salários, vencimentos, proventos, pensões e suas complementações, benefícios previdenciários e indenizações por morte ou por invalidez, fundadas em responsabilidade civil, em virtude de sentença judicial transitada em julgado, e serão pagos com preferência sobre todos os demais débitos, exceto sobre aqueles referidos no $\S 2^{\circ}$ deste artigo.

No mesmo sentido é o entendimento do Egrégio Tribunal Regional Federal da $4^{\mathrm{a}}$ região, decidiu na Ação Cautelar no 501479750-SC, julgada em 01/03/2018: "PREVIDENCIÁRIO. PARCELAS RECEBIDAS DE BOA-FÉ. IRREPETIBILIDADE. São irrepetíveis as parcelas indevidas de benefícios previdenciários recebidas de boa-fé, tendo em vista a sua natureza alimentar."

Acerca da controvérsia surge o questionamento, o segurado que recebeu a título de tutela antecipada benefício previdenciário, caso ocorra a reversibilidade da medida, terá ele que devolver os valores recebidos. 
Dessa forma, o STF se posicionou favoravelmente no Agravo Regimental em Recurso Extraordinário no Agravo de Instrumento ${ }^{\circ}$ 829.651-MG, de Relatoria da Ministra Rosa Weber, julgado em 02/09/2013: "A jurisprudência desta Corte firmou-se no sentido de que o benefício previdenciário recebido de boa-fé pelo segurado em virtude de decisão judicial não está sujeito à repetição de indébito, dado o seu caráter alimentar."

Considerando o caráter alimentar dos benefícios previdenciários legitimado no texto constitucional, as verbas são destinadas ao sustento, dentre eles evidencia-se a proteção aos bens jurídicos de suma importância, sendo eles: à vida, educação, saúde dentre outros previstos nos artigos $5^{\circ}$ e $6^{\circ}$ ambos da Constituição, dessa forma, nota-se que todos os bens jurídicos tutelados estão diretamente ligados à dignidade da pessoa humana.

\section{DA CONSTITUCIONALIDADE DA ANTECIPAÇÃO DOS EFEITOS DA TUTELA}

O processo constitucional não é apenas um direito instrumental, mas uma garantia dos direitos fundamentais. Sabemos que as tutelas de urgência quando relacionadas aos benefícios previdenciários possuem caráter alimentar, em conformidade com o texto constitucional, em concomitância, a Constituição da República proporciona as tutelas a natureza de um dispositivo de proteção, a saber:

Se o Estado passa a ter dever de tutelar os direitos fundamentais, a jurisdição, além de ter que dar atuação às normas que lhes dão proteção e de suprir a omissão de proteção legislativa a estes direitos, obviamente passa a ter que outorgar tutela jurisdicional efetiva (art. 5o, XXXV, CF)e tempestiva (art. 5o, LXXVIII, CF) a todo e qualquer direito. (MARINONI, 2017, pág. 31).

A jurisdição constitucional das liberdades, melhor dizendo, é a garantia de direitos fundamentais na atuação da jurisdição constitucional, acerca da constitucionalidade, José Alfredo de Oliveira Baracho:

O direito à tutela jurisdicional assenta-se como princípio supremo de ordenamento constitucional, que assegura a todos a solução de controvérsias. A proteção jurisdicional de uma situação jurídica, para que seja plenamente efetiva, desdobra-se em decisão de mérito da própria demanda judicial. (BARACHO, 2006, pág. 78).

O processo é uma relação jurídica triangular, onde os interessados exercem o seu direito de ação e esperam que o poder judiciário conceda o provimento ao pedido, e que esta decisão produza efeitos, ou seja, obter a tutela efetiva dos juízes e tribunais a fim de assegurar seus direitos mais básico. Mas, este procedimento não pode ser realizado sem o contraditório, pois é a garantia proporcional de paridade no processo constitucional.

Porém, existem situações nas quais o contraditório poderá ser mitigado. Essa regra se aplica ao artigo $9^{\circ}, \S^{\circ}$, inciso I do CPC, traz o princípio da vedação a decisão surpresa, porém impõe ressalvas as tutelas provisórias de urgência.

\subsection{Vedação das tutelas de urgência contra a fazenda pública}

Há uma controvérsia acerca da aplicação dos índices de correção monetária e juros de mora. Eram adotados os índices e percentuais aplicáveis às cadernetas de poupança, aos segurados do INSS, mas independentemente da natureza da dívida. No entanto, o STF declarou que era inconstitucional tal previsão.

Atualmente, as verbas previdenciárias devem acatar as seguintes medidas: 
Artigo: Antecipação dos efeitos da tutela nos processos de aposentadoria especial à luz do princípio da dignidade da pessoa humana

\begin{abstract}
As condenações impostas à Fazenda Pública de natureza previdenciária sujeitam-se à incidência do INPC, para fins de correção monetária, no que se refere ao período posterior à vigência da Lei $\mathrm{n}^{\circ} 11.430 / 2006$, que incluiu $\mathrm{o}$ art. 41 -A na Lei $\mathrm{n}^{\circ}$ 8.213/91.Quanto aos juros de mora, no período posterior à vigência da Lei ${ }^{\circ}$ 11.960/2009, incidem segundo a remuneração oficial da caderneta de poupança. STJ. $1^{a}$ Seção. REsp 1.495.146-MG, Rel. Min. Mauro Campbell Marques, julgado em 22/02/2018 (recurso repetitivo) (Info 620).
\end{abstract}

Quanto à correção monetária, após a entrada em vigor da Lei n ${ }^{\circ} 11.430 / 2006$, passou a ser considerado o INPC e, não mais os índices previstos no manual de cálculo da Justiça Federal. A Lei $\mathrm{n}^{\mathrm{o}}$ 11.430/2006 incluiu o art. 41-A na Lei $\mathrm{n}^{\circ}$ 8.213/91 com a seguinte redação:

\begin{abstract}
Art. 41-A. O valor dos benefícios em manutenção será reajustado, anualmente, na mesma data do reajuste do salário mínimo, pro rata, de acordo com suas respectivas datas de início ou do último reajustamento, com base no Índice Nacional de Preços ao Consumidor - INPC, apurado pela Fundação Instituto Brasileiro de Geografia e Estatística - IBGE. (Incluído pela Lei no 11.430/2006).
\end{abstract}

Em relação aos juros de mora, foi decidido pela Lei $n^{\circ} 11.960 / 2009$ que deu nova redação ao artigo $1^{\circ}$ - F da Lei 9,494/97 que o juros incidirá sobre índice de remuneração da caderneta de poupança.

[...] Não há inconstitucionalidade na vedação. Nas hipóteses previstas em lei, não é possível, em princípio, haver a tutela de urgência contra a Fazenda Pública. Pode, porém, o juiz, demonstrando fundamentadamente, que a hipótese reclama uma regra de exceção, afastar a norma e conceder medida. O certo, e enfim, é que tais restrições reclamam exegese restritiva, somente sendo vedada a concessão da tutela de urgência nos casos expressamente indicados no dispositivo legal. (CUNHA, 2016, p.306).

Dessa forma, o STF o entendimento é no sentido de que tais restrições são constitucionais, contudo, deverão ser interpretadas estritamente a norma prevista no artigo $1^{\circ}$ da Lei 9.494/97 sendo possível a concessão de tutela de urgência nas hipóteses não tipificadas nos artigos supracitados.

\title{
4.2. Da tutela de urgência concedida em primeiro grau e sua estabilização
}

A estabilização da tutela provisória de urgência de natureza antecipada, "torna-se estável se da decisão que a conceder não for interposto o respectivo recurso", e o artigo 304, " $\$ 1^{\circ}$ - No caso previsto no caput, o processo será extinto". Neste caso, o processo será extinto, mas a tutela de urgência continuará a produzir efeitos. Contudo, a produção de efeitos não fará coisa julgada.

Dessa forma torna-se a mutável e discutível, no entanto, as partes não poderão voltar a discutir o mérito após o prazo decadencial de dois anos, esse prazo começará a contar a partir do conhecimento da decisão que extinguiu o processo.

\subsection{Da tutela de urgência concedida na sentença e seus efeitos no momento da interposição do recurso de apelação}

No Processo Civil, há um debate sobre a efetividade das sentenças que foram julgadas procedentes, ainda, quando há concessão de tutela de urgência no momento sentença, a indagação feita pelos doutrinadores é em relação ao efeito suspensivo. Alguns doutrinadores entendem que quando a ação for julgada procedente e se houver tutela de urgência na ação não 
incidirá o efeito suspensivo, apenas o efeito devolutivo em sede de apelação, conforme Luiz Guilherme Marinoni, assevera:

\begin{abstract}
Nessa perspectiva, é preciso perceber que o novo Código perdeu uma oportunidade importante: poderia ter tolhido o efeito suspensivo da apelação, tornando-o sempre atribuível ope judicis. Isso sem dúvida outorgaria maior coerência ao nosso sistema, na medida em que decisões provisórias fundadas em cognição sumária têm eficácia imediata (tutelas provisórias, arts. 294 e ss.), ao passo que decisões definitivas fundadas em cognição exauriente não contam em regra com a mesma eficácia. Vale dizer: o processo civil brasileiro atribui maior peso em termos de efetividade e tempestividade a decisões provisórias do que a decisões definitivas - nada obstante o juízo que alicerça as primeiras seja evidentemente menos seguro que o juízo que embasa as segundas. O ideal é que todas as decisões judiciais tivessem eficácia imediata, contrabalanceando-se com a possibilidade de sua suspensão ope judicis. Nesse particular, o legislador inadimpliu com o seu dever de desenhar um processo capaz de viabilizar tutela jurisdicional tempestiva (art. 5. ${ }^{\circ}$, LXXVIII, da CF). (MARINONI, 2006, pág. 525).
\end{abstract}

Embora, o efeito suspensivo tenha o objetivo de evitar que a decisão recorrida produza efeitos, deve-se ponderar entre o caráter alimentar do benefício em conjunto com a garantia dos direitos fundamentais à previdência, à saúde e a dignidade humana. Além disso, garantir a segurança jurídica e a equidade processual. Portanto, dentre as decisões dos TRF's, verifica-se que há prática reiterada da concessão das tutelas no momento da sentença. Nesse sentido, quando há interposição de recursos pelo INSS, ele (recurso) é distribuído apenas com o efeito devolutivo, para que haja a garantia ao segurado que esteja recebendo o benefício e não seja prejudicado, pois pode ser que o segurado receba somente esse benefício e o tenha como renda.

Em suma, a tutela antecipada é uma ferramenta que muitos advogados utilizam a fim de antecipar o resultado do julgamento, mas as decisões dos juízes federais de postergar o mérito até o momento da sentença, para conceder a tutela, caso o INSS interponha apelação. O recurso será recebido apenas com o efeito devolutivo, sem a incidência do efeito suspensivo. Dessa forma, a tutela de urgência, mostra-se, ser um instrumento eficaz e uma técnica processual para que o segurado não deixe de receber o seu benefício, tendo em vista garantir o caráter alimentar e a efetividade dos direitos fundamentais.

\title{
5 APOSENTADORIA ESPECIAL
}

A aposentadoria especial é uma das sub-espécie de aposentadoria por tempo de contribuição e é considerada especial em razão do exercício de atividade laboral, a fim de amparar o trabalhador que trabalhou em condições nocivas e perigosas a sua saúde, reduzindo o tempo de serviço/contribuição para fins de aposentadoria. O art. 31 da Lei n. 3.807/1960, que instituiu o benefício, foi mantido pelas legislações seguintes.

A EC n ${ }^{\circ} 103 / 2019$, que alterou substancialmente a redação do $\S 1^{\circ}$ do artigo 201 da $\mathrm{CR} / 88$, determinou que oportunamente a previsão em Lei Complementar dos critérios de idade, o tempo e às contribuições, poderão ser alterados diferentemente do que está previsto na regra geral.

Art. 201. A previdência social será organizada sob a forma do Regime Geral de Previdência Social, de caráter contributivo e de filiação obrigatória, observados critérios que preservem o equilíbrio financeiro e atuarial, e atenderá, na forma da lei, a:

(...)

$\S 1^{\circ}$ É vedada a adoção de requisitos ou critérios diferenciados para concessão de benefícios, ressalvada, nos termos de lei complementar, a possibilidade de 
Artigo: Antecipação dos efeitos da tutela nos processos de aposentadoria especial à luz do princípio da dignidade da pessoa humana

previsão de idade e tempo de contribuição distintos da regra geral para concessão de aposentadoria exclusivamente em favor dos segurados:

(..)

II - cujas atividades sejam exercidas com efetiva exposição a agentes químicos, físicos e biológicos prejudiciais à saúde, ou associação desses agentes, vedada a caracterização por categoria profissional ou ocupação.

Hodiernamente, presente no art. 57, caput, da Lei $n^{\circ}$ 8.213/91, a aposentadoria especial será devida ao segurado que tenha trabalhado em condições especiais que lhe prejudiquem a saúde ou a integridade física, durante 15 (quinze), 20 (vinte) ou 25 (vinte e cinco) anos, conforme dispuser a lei, e desde que, também seja cumprida a carência exigida, de 180 contribuições.

No entanto, o enquadramento da atividade como especial deverá dar-se de acordo com a legislação contemporânea ao tempo da prestação do serviço, de modo mais restritivo, conforme as Leis $\mathrm{n}^{\circ}$ 9.032/95, 9.528/97 e 9.711/98.

Contudo, há de ressaltar que antes da entrada em vigor das aludidas Leis não era necessário a comprovação do tempo de serviço especial, nos termos do art. 274 da IN INSS/PRES 77/2015:

\footnotetext{
Art. 274. Observados os critérios para o enquadramento do tempo de serviço exercido em condições especiais, poderão ser considerados por categoria profissional os períodos em que o segurado exerceu as funções de auxiliar ou ajudante de qualquer das atividades constantes dos quadros anexos aos Decretos n ${ }^{\circ} 53.831$, de 1964 e Decreto $^{\circ}$ 83.080, de 1979, até 28 de abril de 1995, véspera da publicação da Lei $n^{\circ} 9.032$, de 1995, situação em que o enquadramento será possível desde que o trabalho, nessas funções, seja exercido nas mesmas condições e no mesmo ambiente em que trabalha o profissional abrangido por esses decretos.

Parágrafo único. Para o enquadramento previsto no caput, deverá constar expressamente no formulário previsto no art. 260 , a informação de que o segurado tenha exercido as atividades nas mesmas condições e no mesmo ambiente do respectivo profissional. (INSTRUÇÃO NORMATIVA 77/2015).
}

Bastava apenas que a atividade exercida pelo segurado estivesse amparada entre aquelas categorias elencadas nos Decretos 53.831/64 e 83.080/79 (enquadramento por categoria). Destaca-se ainda que, no enquadramento por agente nocivo, o segurado deveria demonstrar que foi submetido por meio do formulário próprio (IS SSS 501.19/71, ISS-132, SB40, DISES BE 5235), não sendo necessário a comprovação por meio de laudo técnico, com à exceção do agente físico ruído, o que será estudado adiante.

Ressalta-se que as Leis supracitadas não são aplicáveis retroativamente, tendo em vista o direito adquirido.

Considerando a significativa sucessão das Leis, que disciplinam a matéria, passa-se, então, a algumas considerações sobre a contagem do tempo de serviço como especial e suas alterações.

\subsection{Principais alterações para conversão de tempo especial}

Neste capítulo estudaremos as alterações na lei para a conversão do tempo especial, dentre elas estão as principais conquistas dos trabalhadores submetidos a agentes nocivos agressivos a saúde e as principais perdas de direito, após a EC n¹03/2019.

\subsubsection{Advento da lei $9.032 / 95$ e seus desdobramentos}


Com o advento da Lei 9.032/95, de 29/04/1995, houve o término do enquadramento do tempo especial por categoria profissional e, estabeleceu-se ao segurado, a imprescindibilidade de comprovar o tempo em que esteve exposto aos agentes nocivos, com a exigência de que esta exposição fosse habitual e permanente. Segundo o artigo 65 do Decreto $n^{\circ} 3.048 / 99$, o tempo de trabalho permanente é aquele exercido de forma não ocasional nem intermitente.

A partir da entrada em vigor da Lei 9.032/95, tornou-se imprescindível a comprovação efetiva da exposição ao agente nocivo pelo Laudo Técnico das Condições Ambientais do Trabalho (LTCAT), de forma habitual e permanente, aos agentes prejudiciais à saúde e à integridade física, por qualquer meio de prova, sendo suficiente a apresentação de formuláriopadrão (Formulário SB 40, atual DSS 8030). Esse formulário seria preenchido pelo empregador, não sendo exigido laudo técnico das condições ambientais, exceto, repita-se, sendo necessária a medição técnica para as atividades em que o segurado estivesse exposto ao agente nocivo ruído.

\subsubsection{A edição da MP 1.523/96}

No tocante aos agentes nocivos a edição da MP ${ }^{\circ} 1.523$, de 11/10/96 que mais tarde veio a se converter na Lei $n^{\circ}$ 9.528/97, de 10/12/1997, relacionou e enumerou os agentes nocivos sendo eles físicos, químicos e biológicos prejudiciais à saúde ou à integridade física, considerando-os para fins de concessão a aposentadoria especial, como definidos pelo Poder Executivo. Além disso, passou a ser obrigatório a exigência das empresas manterem sempre atualizadas os laudos técnicos das condições ambientais, bem como elaborar o Perfil Profissiográfico Previdenciário (PPP) contendo as atividades exercidas pelo trabalhador, sob pena de multa.

Ademais, considerando as condições especiais e insalubre que o segurado é exposto, passou a ser exigido como referência no laudo técnico pericial das formas neutralizadoras para diminuir o agente nocivo, sendo a tecnologia empregada o Equipamento de Proteção Individual (EPI), de uso obrigatório.

A classificação dos agentes nocivos físicos, químicos e biológicos não deve ser considerada exaustiva, mas enumerativa. No mesmo sentido, os critérios de avaliação, a que se refere o $\S 2^{\circ}$ do artigo 68 do Decreto 3,048/99 com redação dada pela Lei 8.123/13, no ambiente de trabalho, compreendem-se, em função e em razão da natureza, concentração, intensidade e fator de exposição.

\subsubsection{A EC n' $103 / 2019$ e a vedação da conversão}

A partir da entrada em vigor da EC n ${ }^{\circ} 103 / 2019$, ficou determinado que não há como considerar a conversão do tempo especial em tempo comum para os períodos laborados após a vigência da nova Emenda Constitucional.

Art. 25. Será assegurada a contagem de tempo de contribuição fíctício no Regime Geral de Previdência Social decorrente de hipóteses descritas na legislação vigente até a data de entrada em vigor desta Emenda Constitucional para fins de concessão de aposentadoria, observando-se, a partir da sua entrada em vigor.

$\S 2^{\circ}$ Será reconhecida a conversão de tempo especial em comum, na forma prevista na Lei $n^{\circ} 8.213$, de 24 de julho de 1991, ao segurado do Regime Geral de Previdência Social que comprovar tempo de efetivo exercício de atividade sujeita a condições especiais que efetivamente prejudiquem a saúde, cumprido até a data de entrada em vigor desta Emenda Constitucional, vedada a conversão para o tempo cumprido após esta data. 
Artigo: Antecipação dos efeitos da tutela nos processos de aposentadoria especial à luz do princípio da dignidade da pessoa humana

Verifica-se que a EC, $\mathrm{n}^{\mathrm{o}}$ 103/2019 é prejudicial aos trabalhadores que exercem atividades expostos a agente nocivos.

Ao afirmarmos que estas mudanças são prejudiciais aos trabalhadores submetidos a agentes nocivos, com relação a soma mínima da idade e o tempo de contribuição, não há qualquer diferenciação entre homens e mulheres, porque são exigidos a mesma pontuação:

\footnotetext{
Art. 201. A previdência social será organizada sob a forma do Regime Geral de Previdência Social, de caráter contributivo e de filiação obrigatória, observados critérios que preservem o equilíbrio financeiro e atuarial, e atenderá, na forma da lei, a:

$\S 1^{\circ}$ É vedada a adoção de requisitos ou critérios diferenciados para concessão de benefícios, ressalvada, nos termos de lei complementar, a possibilidade de previsão de idade e tempo de contribuição distintos da regra geral para concessão de aposentadoria exclusivamente em favor dos segurados:

II - cujas atividades sejam exercidas com efetiva exposição a agentes químicos, físicos e biológicos prejudiciais à saúde, ou associação desses agentes, vedada a caracterização por categoria profissional ou ocupação.
}

Contudo, não há lei complementar que normatizando a matéria, desse modo, a EC $\mathrm{n}^{\circ} 103$, determina provisoriamente a idade mínima em seu artigo $19, \S 1^{\circ}$, o qual ficou estipulado que 55 anos de idade para 15 anos de contribuição na atividade considerada especial 58 anos de idade para 20 anos de contribuição e 60 anos de idade para 25 anos de contribuição.

A criação do requisito etário é inconstitucional, pois irá obrigar o segurado a permanecer trabalhando em ambiente insalubre por tempo superior ao tempo mínimo quando a implementação do requisito tempo de contribuição de 15, 20 e 25 anos.

Quanto ao destinatário da aposentadoria especial, por trabalhar exposto a risco à sua saúde ou integridade física, não pode ele aguardar eventual idade mínima, nesta espécie, sob pena de ter que permanecer exposto ao risco, o que viola o art. $7^{\circ}$, XXII, da Constituição Federal.

\footnotetext{
Art. $7^{\circ}$ São direitos dos trabalhadores urbanos e rurais, além de outros que visem à melhoria de sua condição social:

(...)

XXII - redução dos riscos inerentes ao trabalho, por meio de normas de saúde, higiene e segurança; [...].
}

Se para a concessão da aposentadoria especial determinou um tempo de exposição para o trabalhador, ao argumento de que os agentes nocivos poderiam causar danos irreparáveis à saúde do trabalhador, não seria necessário impor outro requisito, o etário. Tendo em vista que há perda da capacidade laborativa no longo do tempo de serviço necessário à aposentação e o tempo para completar a idade para fazer jus ao benefício.

Além disso, a EC nº103, inovou em não pagar $100 \%$ da média salarial, o cálculo da nova regra previdenciária estabelece que o homem que se aposentar com tempo de contribuição entre 15 e 20 anos terá $60 \%$ (sessenta por cento) da média salarial e mais $2 \%$ (dois por cento) a cada ano que exceder o trabalho especial. $\mathrm{O}$ que viola os seguintes princípios previstos na constituição a começar pela valorização do trabalho nos termos do artigo 170, em seguida ordem social que tem como um de seus pilares o trabalho, conforme o artigo 193 e, por fim, a seguridade social que se propõe a assegurar os direitos relativos à saúde, à previdência e à assistência social. Nesse sentido o artigo 194, dispõe em incisos I, II, III e IV, todos da constituição da república, questões relativas à universalidade de atendimento ao segurado, uniformidade e equivalência dos benefícios prestados aos segurados que residem em zona rural e urbana, seletividade e a distributividade dos benefícios e, finalmente, a irredutibilidade do valor do benefício recebido pelos segurados. 


\title{
5.2. Comprovação do exercício da atividade especial
}

A demonstração das condições insalubres do ambiente de trabalho, a que ocasiona o direito à aposentadoria especial será comprovada por meio de prova documental específica, tal demonstração deverá caracterizar as condições ambientais e a prova efetiva da exposição do segurado ao agente nocivo.

\subsubsection{Laudo técnico de condições ambientais - LTCAT}

O Laudo Técnico de Condições Ambientais passou a ser exigido a partir Lei 9.032/95, tornando se necessário a sua elaboração do LTCAT para comprovar da exposição do trabalhador aos agentes nocivos.

Assim, dispõe a legislação atual (Lei 8.213/91, art. 58, $\S \S 1^{\circ}$ e $4^{\circ}$ ):

\begin{abstract}
Art. 58 (...)
$\S 1^{\circ}$ A comprovação da efetiva exposição do segurado aos agentes nocivos será feita mediante formulário, na forma estabelecida pelo Instituto Nacional do Seguro Social - INSS, emitido pela empresa ou seu preposto, com base em laudo técnico de condições ambientais do trabalho expedido por médico do trabalho ou engenheiro de segurança do trabalho nos termos da legislação trabalhista.

(..)

$\S 4^{\circ} \mathrm{A}$ empresa deverá elaborar e manter atualizado perfil profissiográfico abrangendo as atividades desenvolvidas pelo trabalhador e fornecer a este, quando da rescisão do contrato de trabalho, cópia autêntica desse documento[...].
\end{abstract}

No tocante ao período em que se tornou obrigatória a apresentação do LTCAT, no caso do agente nocivo Ruído, o Conselho de Recursos da Previdência Social (CRPS) editou o Enunciado $n^{\circ} 20$ :

\footnotetext{
Salvo em relação ao agente agressivo ruído, não será obrigatória a apresentação de laudo técnico pericial para períodos de atividades anteriores à edição da Medida Provisória n. 1.523-10, de 11.10.96, facultando-se ao segurado a comprovação de efetiva exposição a agentes agressivos à sua saúde ou integridade física mencionados nos formulários SB-40 ou DSS-8030, mediante o emprego de qualquer meio de prova em direito admitido. (ENUNCIADO $\mathrm{n}^{\circ} 20$ ).
}

Nesse sentido, pacificou o entendimento de que a exigência do LTCAT seria válida após o Decreto 2.172/97, não sendo aplicado aos casos em que o agente nocivo é o ruído.

Nos termos do art. 264, $§ 1^{\circ}$, da IN INSS/PRES 77/2015:

[...] o PPP deverá ser assinado por representante legal da empresa ou seu preposto, que assumirá a responsabilidade sobre a fidedignidade das informações prestadas quanto a: a) fiel transcrição dos registros administrativos; e b) veracidade das demonstrações ambientais e dos programas médicos de responsabilidade da empresa [...]. (INSTRUÇÃO NORMATIVA, 77/2015).

O único documento exigido pelo INSS passou a ser o referido PPP, que deve ser embasado em laudo técnico ou em perícia técnica e seu preenchimento deve ser feito por responsável técnico habilitado, mas o Laudo deve permanecer na empresa, à disposição da Autarquia.

\subsubsection{Perfil profissiográfico previdenciário - PPP}


Artigo: Antecipação dos efeitos da tutela nos processos de aposentadoria especial à luz do princípio da dignidade da pessoa humana

O PPP é o documento do histórico da atividade laboral e tem como finalidade identificar os trabalhadores expostos ou submetido a agentes nocivos à saúde.

O modelo do PPP, instituído pelo INSS, deverá constar o nome dos responsáveis das avaliações ambientais, os resultados das monitorações e os dados administrativos.

Nessa lógica, o PPP necessitará ser atualizado a cada ano ou quando ocorrer alteração no ambiente de trabalho ou quando houver a troca de atividade pelo trabalhador.

A elaboração do PPP é feita pela empresa ou equiparada à empresa e para cada empregado deverá ser produzido de forma individualizada, esse tratamento também é utilizados para os trabalhadores avulsos e os cooperados, que praticam atividade laboral submetido aos agentes nocivos químicos, físicos e biológicos.

Há uma exigência em relação a elaboração do PPP, quanto ao agente físico Ruído. De acordo com a Norma Regulamentadora $n^{\circ} 9$ (NR) do Ministério do Trabalho e Economia (MTE), nesse caso vincula os níveis das ações dos agentes nocivos presentes no ambiente de trabalho.

O PPP é documento hábil e suficiente sendo um meio de demonstração e comprovação da exposição do trabalhador ao agente nocivo, em se tratando de ruído, independentemente da apresentação do respectivo laudo técnico ambiental (PU 2009.71.62.001838-7, Rel. Juiz Federal Herculano Martins Nacif, DOU de 22.3.2013). Orientação da Turma Nacional de Uniformização foi legitimada pelo STJ, e súmula 68 TNU:

PEDIDO DE UNIFORMIZAÇÃO DE JURISPRUDÊNCIA. PREVIDENCIÁRIO. COMPROVAÇÃO DE TEMPO DE SERVIÇO ESPECIAL. RUÍDO. PERFIL PROFISSIOGRÁFICO PREVIDENCIÁRIO (PPP). APRESENTAÇÃO SIMULTÂNEA DO RESPECTIVO LAUDO TÉCNICO DE CONDIÇÕES AMBIENTAIS DE TRABALHO (LTCAT). DESNECESSIDADE QUANDO AUSENTE IDÔNEA IMPUGNAÇÃO AO CONTEÚDO DO PPP. (STJ, PET 10.262/RS, $1^{\text {a }}$ Seção, Ministro Sérgio Kukina, DJe 16.2.2017).

Súmula 68: O laudo pericial não contemporâneo ao período trabalhado é apto à comprovação da atividade especial do segurado. (TNU-JEF, DOU de 24/09/2012, p. 114).

Em caso de dúvidas ou não sendo suficiente o PPP para a comprovação, mostra-se necessário a produção de prova pericial, ainda que seja impossível a realização da perícia, será admitida a perícia indireta ou por similitude e será realizado por meio de estudo técnico em outro estabelecimento cuja as condições de trabalho sejam semelhantes a atividade exercida. Nesse contexto, o STJ julgou o Recurso Especial:

É possível, em virtude da desconfiguração da original condição de trabalho da exempregadora, a realização de laudo pericial em empresa do mesmo ramo de atividade, com o exame de local com características similares ao daquele laborado pelo obreiro, a fim de apurar a efetiva exposição do segurado aos agentes nocivos, para reconhecimento do direito à contagem de tempo especial de serviço. (REsp 1.428.183/RS, DJe de 6.3.2014).

Nota-se que o PPP será produzido a partir do LTCAT, em modelo próprio exigido pelo INSS, assinado pelos responsáveis médicos, engenheiros do trabalho, assim como o técnico em segurança do trabalho, deverão estar atualizado, pois é documento individual.

\subsubsection{Equipamento de proteção individual - EPI}


O EPI é todo material de uso individual que o trabalhador utiliza dentro de sua função no ambiente de trabalho, com a finalidade proteger a sua integridade física, sua segurança e sua saúde em seu ofício, conforme o disposto na NR 6 do Ministério do Trabalho e Economia.

Este dispositivo atribuiu aos empregadores alguns deveres, dentre eles: exigência de seu uso, fornecimento adequado do EPI ao trabalhador, possuir material aprovado pelo órgão nacional competente relativo à segurança e à saúde no trabalho. Além disso, orientar e treinar o funcionário sobre o uso adequado, no que concerne a conservação do EPI, substituir imediatamente, quando ele for danificado, assim como comunicar ao MTE irregularidade de qualquer natureza, bem como se responsabilizar pela higienização e manutenção periódica e, por fim, registrar seu fornecimento ao trabalhador a fim de se resguardar de eventuais problemas.

Neste sentido, o disposto supracitado também atribui ao empregado alguns deveres, sendo o de usar apenas para a finalidade de seu labor, bem como a responsabilidade da guarda e conservação, ademais comunicar ao seu superior qualquer alteração que o torne impróprio ao uso.

Importante ainda mencionar que o Enunciado $\mathrm{n}^{\circ} 21$ do CRPS relativo ao EPI, quando fornecido pelo empregador, não exclui a hipótese de exposição ao trabalhador ao agente nocivo. Neste caso deve-se analisar o ambiente de trabalho no todo e não em partes.

Dessa forma, entendeu o Egrégio Tribunal Superior do Trabalho ao editar a Súmula 289:

O simples fornecimento do aparelho de proteção pelo empregador não o exime do pagamento do adicional de insalubridade. Cabe-lhe tomar as medidas que conduzam à diminuição ou eliminação da nocividade, entre as quais as relativas ao uso efetivo do equipamento pelo empregado. (TST, DOU de 21/11/2003).

O considera-se que o simples fato de o empregador fornecer o EPI não o exime do pagamento do adicional de insalubridade, art. $7^{\circ}$, XXII da CR/88.

No que diz respeito ao agente nocivo ruído, a Turma Nacional de Uniformização dos Juizados Especiais Federais editou a Súmula $n^{\circ} 9$ "O uso de Equipamento de Proteção Individual (EPI), ainda que elimine a insalubridade, no caso de exposição a ruído, não descaracteriza o tempo de serviço especial prestado", pois houve a necessidade de reconhecer que referido agente nocivo causa danos, não apenas no aparelho auditivo, mas alterações físicas e psíquicas. Assim, o STF reconheceu a existência de Repercussão Geral em relação à validade do "uso do EPI" para afastar a especialidade do labor.

Foram fixadas duas teses a respeito ARE 664.335, julgado em 04/12/2014, as quais, consideram-se que:

[...] o direito à aposentadoria especial pressupõe a efetiva exposição do trabalhador a agente nocivo à sua saúde, de modo que, se o EPI for realmente capaz de neutralizar a nocividade não haverá respaldo constitucional à aposentadoria especial. (Citação extraída da Ementa ARE 664335/SC).

Ainda sim,

[...]a segunda tese a ser fixada neste Recurso Extraordinário é a seguinte: na hipótese de exposição do trabalhador a ruído acima dos limites legais de tolerância, a declaração do empregador, no âmbito do Perfil Profissiográfico Previdenciário (PPP), no sentido da eficácia do Equipamento de Proteção Individual - EPI, não descaracteriza o tempo de serviço especial para aposentadoria. (Citação extraída da Ementa do ARE 664335/SC). 
Artigo: Antecipação dos efeitos da tutela nos processos de aposentadoria especial à luz do princípio da dignidade da pessoa humana

Quando se trata de ações que questionam o reconhecimento do tempo especial desse agente, no julgado em questão, os Ministros do STF entenderam que o EPI realmente é capaz de neutralizar a nocividade do agente físico ao qual o trabalhador é exposto, exceto, quando o trabalhador estiver exposto a ruído acima dos limites legais de tolerância.

Neste caso, não há que se falar em ofensa ao princípio da isonomia em relação aos trabalhadores expostos a limites inferiores aos patamares legais e que não usam EPI, dado que esses não são expostos, ainda que potencialmente, ao ruído considerado nocivo pela Lei, o que justifica receber o tratamento diferenciado aos trabalhadores submetidos a essas condições, ainda àqueles que estes estejam usando EPI sendo ele considerado eficaz. Desse modo, percebese não ser o EPI eficaz a nocividade do Ruído.

\subsection{Agente nocivo: ruído e as principais consequências}

De acordo com a NR 15 do MTE, que regulamentou os níveis de ruído acima dos limites, deve-se considerar como agressivo à saúde, a exposição a locais de trabalho com ruídos acima de 80 decibéis, na vigência do Decreto $n^{\circ} 53.831 / 64$, ou seja, até 05/03/1997; superior a 90 decibéis, na vigência do Decreto no 2.172/1997 (período de 06/03/1997 a 18/11/2003); e superior a 85 decibéis, a partir da edição do Decreto n 4.882/2003 (a partir de 19/11/2003) e da Instrução Normativa $n^{\circ} 20$, de 10/10/2007, do INSS, art. 180, conforme entendimento pacificado pelo STJ.

Ainda há que se ressaltar, mesmo se houver informação no PPP de que o fornecimento de equipamento de proteção individual eficaz não poderá descaracterizar o tempo de serviço especial se houver a exposição ao agente ruído acima dos limites de tolerância, pois, nesta condição a nocividade não é neutralizada.

O Certificado de Aprovação do EPI também não é suficiente para comprovar a eficácia plena, sendo o posicionamento doutrinário, como afirma Fernando Vieira Marcelo, mencionado no referido julgado do STF, senão vejamos:

[...] a avaliação sobre a neutralização do risco dos agentes nocivos não é resolvida pela simples verificação do certificado de aprovação (CA) dos protetores auriculares. Se assim fosse, as normas técnicas previstas na NR 09 que regulam a periodicidade regular, treinamentos, uso adequado, adequação da proteção à atividade e ao usuário seriam letras mortas. De tudo, conclui-se: a) como nenhum órgão competente comprovou a inexistência do risco à saúde do segurado; b) como a simples análise do CA e a simples informação de entrega de EPIs não são suficientes para comprovar a neutralização dos agentes agressivos; c) a insalubridade não pode ser descaracterizada. (Citação extraída do ARE 664335/SC, fl. 69).

Por fim, na comparação do ruído, a variável a ser considerada no PPP é o ruído médio equivalente (LEq) e não o ruído máximo aferido nem a simples média entre os ruídos mínimo e máximo. Também deve ser analisado o ruído no PPP quando há oscilação e se há um número máximo e um número mínimo.

\subsection{Benefício mais vantajoso}

Com relação a concessão do benefício mais vantajoso, dispõe artigos 687 e 690, parágrafo único, da Instrução Normativa INSS/PRES 77, de 21 de janeiro de 2015.

Art. 687. O INSS deve conceder o melhor benefício a que o segurado fizer jus, cabendo ao servidor orientar nesse sentido.

Art. 688. Quando, por ocasião da decisão, for identificado que estão satisfeitos os requisitos para mais de um tipo de benefício, cabe ao INSS oferecer ao segurado o 
direito de opção, mediante a apresentação dos demonstrativos financeiros de cada um deles.

$\S 1^{\circ}$ A opção deverá ser expressa e constar nos autos.

$\S 2^{\circ}$ Nos casos previstos no caput, deverá ser observada a seguinte disposição:

I - se os benefícios forem do mesmo grupo, conforme disposto no art. 669 , a DER será mantida; e

II - se os benefícios forem de grupos distintos, e o segurado optar por aquele que não requereu inicialmente, a DER será fixada na data da habilitação do benefício, conforme art. 669.

Art. 689. Se por ocasião do atendimento estiverem presentes as condições necessárias, será imediatamente proferida a decisão.

Já no caso do artigo 690, da IN/77 de 2015, o segurado que preencheu as condições posteriormente fará jus ao benefício mais vantajoso:

Art. 690. Se durante a análise do requerimento for verificado que na DER o segurado não satisfazia os requisitos para o reconhecimento do direito, mas que os implementou em momento posterior, deverá o servidor informar ao interessado sobre a possibilidade de reafirmação da DER, exigindo-se para sua efetivação a expressa concordância por escrito.

Parágrafo único. O disposto no caput aplica-se a todas as situações que resultem em benefício mais vantajoso ao interessado.

Não há óbice legal à concessão do benefício mais vantajoso, tal medida não será considerada como julgamento ultra ou extra petita nem tão pouco "reformatio in pejus", neste caso é garantido ao segurado o direito de receber o benefício mais vantajoso, sendo tal prerrogativa calcada especialmente na natureza social das normas previdenciárias.

\subsection{Conversão do tempo especial em comum}

A conversão do tempo especial em tempo comum se dá em razão de não ter o segurado tempo especial de contribuição suficiente a preencher os requisitos da legislação. Àqueles que trabalham em condições consideradas como especiais e prejudiciais à saúde e à integridade física, a Emenda Constitucional $n^{\circ} 20$, que manteve a vigência dos arts. 57 e 58 da Lei ${ }^{\circ}$ $8.213 / 91$.

De acordo com o disposto no $\S 5^{\circ}$ do art. 57 da Lei 8.213/91:

O tempo de trabalho exercido sob condições especiais que sejam ou venham a ser consideradas prejudiciais à saúde ou à integridade física será somado, após a respectiva conversão ao tempo de trabalho exercido em atividade comum, segundo critérios estabelecidos pelo Ministério da Previdência e Assistência Social, para efeito de concessão de qualquer benefício.

Nesse sentido, eram considerados os fatores de conversão para homens, fator 1,4 e para mulheres, 1,2, constantes da tabela do art. 70 do Regulamento da Previdência Social, com a redação dada pelo Decreto 4.827/2003.

Tal dispositivo atendia o Princípio da Dignidade da Pessoa Humana, o Devido Processo Legal e as garantias constitucionais dos trabalhadores. Além disso, permitiu ao judiciário julgar de forma ampla, adotando a tese e invocando o princípio da fungibilidade dos benefícios e da hipossuficiência, sendo eles, considerados sob o prisma da razoabilidade.

Cite-se o seguinte precedente do Tribunal Regional Federal (TRF) da $1^{\text {a }}$ Região:

Em se tratando de questões previdenciárias, é possível conceder benefício diverso daquele pleiteado, sem que isso caracterize um julgamento extra ou ultra petita, 
Artigo: Antecipação dos efeitos da tutela nos processos de aposentadoria especial à luz do princípio da dignidade da pessoa humana

conforme entendimento firmado por este Tribunal." (AC 2008.01.99.039906-3/MG; Desembargador Federal Antônio Sávio de Oliveira Chaves; $1^{a}$ Turma; 26/02/2009 eDJF1 p.95).

Contudo, com a Emenda Constitucional $n^{\circ} 103$, de 2019, a conversão do tempo especial em tempo comum foi vedada, conforme dispõe o artigo $25, \S 2^{\circ}$ :

\begin{abstract}
Art. 25. Será assegurada a contagem de tempo de contribuição fictício no Regime Geral de Previdência Social decorrente de hipóteses descritas na legislação vigente até a data de entrada em vigor desta Emenda Constitucional para fins de concessão de aposentadoria, observando-se, a partir da sua entrada em vigor, o disposto no $§ 14$ do art. 201 da Constituição Federal.

$\S 2^{\circ}$ Será reconhecida a conversão de tempo especial em comum, na forma prevista na Lei $\mathrm{n}^{\circ}$ 8.213, de 24 de julho de 1991, ao segurado do Regime Geral de Previdência Social que comprovar tempo de efetivo exercício de atividade sujeita a condições especiais que efetivamente prejudiquem a saúde, cumprido até a data de entrada em vigor desta Emenda Constitucional, vedada a conversão para o tempo cumprido após esta data.
\end{abstract}

A partir da interpretação deste dispositivo, será considerado a conversão do tempo especial em comum cumprido até a data de entrada em vigor da EC 103, vedada a conversão para o tempo cumprido após esta data.

A grande questão a ser discutida após a entrada em vigor da EC nº3/19, é como o segurado vai usar esse tempo especial? Como o INSS vai considerar o tempo especial não suficiente para fins de aposentadoria especial? A partir da EC $n^{\circ} 103 / 19$ aposentadoria especial cumpre a sua finalidade?

Ocorre que antes da referida Emenda entrar em vigor, era possível a conversão de tempo especial em comum, a fim de garantir ao segurado o direito a aposentadoria por tempo de contribuição sem a incidência do fator previdenciário, ou seja, era utilizado o princípio da Fungibilidade, e consequentemente, concedido o benefício mais vantajoso ao trabalhador.

Com base nas novas regras, a aposentadoria especial deixará de atender a sua finalidade e seu caráter social, tendo em vista que a maioria dos segurados submetido a agentes nocivos, como é o caso do ruído que, apesar do uso do EPI, não é capaz de neutralizar os agentes. Estaria a $E C n^{\circ} 103 / 19$ violando preceitos fundamentais previstos no artigo 60, $\$ 4$, inciso IV:

Art. 60. A Constituição poderá ser emendada mediante proposta:

$\S 4^{\circ}$ Não será objeto de deliberação a proposta de emenda tendente a abolir:

IV - os direitos e garantias individuais.

A propósito a aposentadoria especial assegura contagem diferenciada do tempo trabalhado exposto a agentes agressivos. E a razão dessa distinção com o segurado que trabalha em ambiente salubre se deu justamente para preservar-lhe a vida, sem a qual não se pode assegurar a dignidade humana, pois essa não existe sem aquela.

\title{
5.6. Fonte de custeio
}

Em relação à fonte de custeio da aposentadoria especial, esse será financiado com os recursos provenientes das contribuições das empresas, conforme dispõe no artigo 22, inciso II, alínea "b" da Lei 8.212/91 e artigo $57, \S 6^{\circ}$ da Lei 8.213/91 e será cobrada a alíquota adicional de contribuição para o custeio do benefício da aposentadoria especial:

Art. 22. A contribuição a cargo da empresa, destinada à Seguridade Social, além do disposto no art. 23, é de: 
II - para o financiamento do benefício previsto nos arts. 57 e 58 da Lei no 8.213 , de 24 de julho de 1991, e daqueles concedidos em razão do grau de incidência de incapacidade laborativa decorrente dos riscos ambientais do trabalho, sobre o total das remunerações pagas ou creditadas, no decorrer do mês, aos segurados empregados e trabalhadores avulsos:

a) $1 \%$ (um por cento) para as empresas em cuja atividade preponderante o risco de acidentes do trabalho seja considerado leve;

b) $2 \%$ (dois por cento) para as empresas em cuja atividade preponderante esse risco seja considerado médio;

c) $3 \%$ (três por cento) para as empresas em cuja atividade preponderante esse risco seja considerado grave.

Art. 57. A aposentadoria especial será devida, uma vez cumprida a carência exigida nesta Lei, ao segurado que tiver trabalhado sujeito a condições especiais que prejudiquem a saúde ou a integridade física, durante 15 (quinze), 20 (vinte) ou 25 (vinte e cinco) anos, conforme dispuser a lei.

$\S 6^{\circ} \mathrm{O}$ benefício previsto neste artigo será financiado com os recursos provenientes da contribuição de que trata o inciso II do art. 22 da Lei $n^{\ominus}$ 8.212, de 24 de julho de 1991, cujas alíquotas serão acrescidas de doze, nove ou seis pontos percentuais, conforme a atividade exercida pelo segurado a serviço da empresa permita a concessão de aposentadoria especial após quinze, vinte ou vinte e cinco anos de contribuição, respectivamente.

Assim, em sede de julgamento do Agravo (ARE) 664335/SC, com repercussão geral reconhecida, decidiu o Supremo Tribunal Federal que o referido benefício será financiado com recursos provenientes da contribuição à que se trata o inciso II do art. 22 da Lei $n^{\circ} 8.212 / 91$, in verbis:

[...] 5. A norma inscrita no art. 195, § 5º CRFB/88, veda a criação, majoração ou extensão de benefício sem a correspondente fonte de custeio, disposição dirigida ao legislador ordinário, sendo inexigível quando se tratar de benefício criado diretamente pela Constituição. Deveras, o direito à aposentadoria especial foi outorgado aos seus destinatários por norma constitucional (em sua origem o art. 202, e atualmente o art. 201, § 1 ${ }^{\circ}$, CRFB/88). Precedentes: RE 151.106 AgR/SP, Rel. Min. Celso de Mello, julgamento em 28/09/1993, Primeira Turma, DJ de 26/11/93; RE 220.742, Rel. Min. Néri da Silveira, julgamento em 03/03/98, Segunda Turma, DJ de 04/09/1998.

6. Existência de fonte de custeio para o direito à aposentadoria especial antes, através dos instrumentos tradicionais de financiamento da previdência social mencionados no art. 195, da CRFB/88, e depois da Medida Provisória $\mathrm{n}^{\circ} 1.729 / 98$, posteriormente convertida na Lei $\mathrm{n}^{\circ}$ 9.732, de 11 de dezembro de 1998 . Legislação que, ao reformular o seu modelo de financiamento, inseriu os $\S \S 6^{\circ}$ e $7^{\circ}$ no art. 57 da Lei n. ${ }^{\circ} 8.213 / 91$, e estabeleceu que este benefício será financiado com recursos provenientes da contribuição de que trata o inciso II do art. 22 da Lei $n^{\circ} 8.212 / 91$, cujas alíquotas serão acrescidas de doze, nove ou seis pontos percentuais, conforme a atividade exercida pelo segurado a serviço da empresa permita a concessão de aposentadoria especial após quinze, vinte ou vinte e cinco anos de contribuição, respectivamente. (Trecho extraído da ementa do ARE 664335/SC).

Com relação a aplicação dos percentuais, incidem eles sobre o total da remuneração a ser paga, destinadas ao segurado empregado ou trabalhador avulso que exerce atividade laboral exposto a certo grau de periculosidade, quanto ao agente nocivo é o ruído é considerado atividade de risco de grau médio, devendo ser cobrada alíquota de $2 \%$ incidente sobre o total das remunerações.

\section{RECURSO EXTRAORDINÁRIO COM AGRAVO 664.335 SANTA CATARINA}


Artigo: Antecipação dos efeitos da tutela nos processos de aposentadoria especial à luz do princípio da dignidade da pessoa humana

No julgamento em questão do recurso extraordinário com agravo 664.335/SC, com repercussão geral reconhecida, que se segue. Apresenta a importância do uso do EPI, porém, ressalta que o equipamento não é suficiente a neutralização do agente nocivo ruído.

Além disso, o recurso coloca em evidência os Direitos Fundamentais à previdência, à saúde, à dignidade da pessoa humana e ao meio ambiente de trabalho.

[...]Destarte, a aposentadoria especial segue o mesmo rumo. O risco aplicável é o exercício de atividade em condições prejudiciais à saúde ou à integridade física (CRFB/88, art. 201, § $1^{\circ}$ ), de forma que torna-se indispensável que o indivíduo trabalhe exposto a uma nocividade notadamente capaz de ensejar o referido dano. Entretanto, independentemente da ocorrência do dano, o que se está a tutelar é a exposição do segurado àquela condição, pelo risco presumido que a relação entre agente nocivo e trabalhador poderá ocasionar. Bem por isso, a desconsideração da eficácia do EPI para a concessão do benefício, como defendem alguns, é alargar a hipótese de sua incidência e tornar irrelevante sua própria essência, ou seja, proteger o trabalhador do risco social do trabalho em condições prejudiciais à saúde[...]. (Trecho extraído do ARE 664335/SC, pág. 20).

Reconheceu o caráter preventivo do benefício de aposentadoria especial, em relação ao segurado que sofre as consequências desgaste naturalmente maior no ambiente de trabalho, em comparação com outras atividades laboral.

4. A aposentadoria especial possui nítido caráter preventivo e impõe se para aqueles trabalhadores que laboram expostos a agentes prejudiciais à saúde e a fortiori possuem um desgaste naturalmente maior, por que não se lhes pode exigir o cumprimento do mesmo tempo de contribuição que aqueles empregados que não se encontram expostos a nenhum agente nocivo. (Trecho extraído da ementa do ARE 664335/SC).

Dessa forma o recurso evidencia o entendimento fixado pelo Supremo Tribunal Federal (STF), no julgamento do Agravo (ARE) 664335, com repercussão geral reconhecida. No sentido de que:

8. O risco social aplicável ao benefício previdenciário da aposentadoria especial é o exercício de atividade em condições prejudiciais à saúde ou à integridade física (CRFB/88, art. 201, $\S 1^{\circ}$ ), de forma que torna indispensável que o indivíduo trabalhe exposto a uma nocividade notadamente capaz de ensejar o referido dano, porquanto a tutela legal considera a exposição do segurado pelo risco presumido presente na relação entre agente nocivo e o trabalhador. 9. A interpretação do instituto da aposentadoria especial mais consentânea com o texto constitucional é aquela que conduz a uma proteção efetiva do trabalhador, considerando o benefício da aposentadoria especial excepcional, destinado ao segurado que efetivamente exerceu suas atividades laborativas em "condições especiais que prejudiquem a saúde ou a integridade física (...) 13. Ainda que se pudesse aceitar que o problema causado pela exposição ao ruído relacionasse apenas à perda das funções auditivas, o que indubitavelmente não é o caso, é certo que não se pode garantir uma eficácia real na eliminação dos efeitos do agente nocivo ruído com a simples utilização de EPI, pois são inúmeros os fatores que influenciam na sua efetividade, dentro dos quais muitos são impassíveis de um controle efetivo, tanto pelas empresas, quanto pelos trabalhadores. (Trecho retirado da Ementa ARE 664335/SC).

Em caso de dúvida sobre a eficácia do EPI, o julgado traz:

[...] Administração poderá, no exercício da fiscalização, aferir as informações prestadas pela empresa, sem prejuízo do inafastável judicial review. Em caso de divergência ou dúvida sobre a real eficácia do Equipamento de Proteção Individual, a premissa a nortear a Administração e o Judiciário é pelo reconhecimento do direito ao 
benefício da aposentadoria especial. Isto porque o uso do EPI, no caso concreto, não pode se afigurar suficiente para descaracterizar completamente a relação nociva a que o empregado se submete [...]. (Citação extraída da Ementa ARE 664335/SC ,pág.4).

No julgado em questão, os Ministros do STF adotaram a tese que se segue: No que diz respeito ao EPI, ele é realmente capaz de neutralizar a nocividade dos agentes, os quais estão submetidos os trabalhadores. Nesse sentido, não haverá respaldo à concessão constitucional do benefício de aposentadoria especial. Embora com uma exceção e são os casos em que o trabalhador estiver exposto aos agentes físicos, em especial o ruído acima dos limites legais de tolerância, a utilização do EPI não será reconhecida como agente redutor da nocividade.

Acerca da nocividade do agente ruído reconheceu que os recursos provenientes da contribuição de $2 \%$ previsto no artigo 22 , inciso II, da Lei 8.212/91:

5. A norma inscrita no art. $195, \S 5^{\circ}, \mathrm{CRFB} / 88$, veda a criação, majoração ou extensão de benefício sem a correspondente fonte de custeio, disposição dirigida ao legislador ordinário, sendo inexigível quando se tratar de benefício criado diretamente pela Constituição. Deveras, o direito à aposentadoria especial foi outorgado aos seus destinatários por norma constitucional (em sua origem o art. 202, e atualmente o art. 201, § 1 , CRFB/88). Precedentes: RE 151.106 AgR/SP, Rel. Min. Celso de Mello, julgamento em 28/09/1993, Primeira Turma, DJ de 26/11/93; RE 220.742, Rel. Min. Néri da Silveira, julgamento em 03/03/98, Segunda Turma, DJ de 04/09/1998.6. Existência de fonte de custeio para o direito à aposentadoria especial antes, através dos instrumentos tradicionais de financiamento da previdência social mencionados no art. 195, da CRFB/88, e depois da Medida Provisória ${ }^{\circ} 1.729 / 98$, posteriormente convertida na Lei $\mathrm{n}^{\circ}$ 9.732, de 11 de dezembro de 1998. Legislação que, ao reformular o seu modelo de financiamento, inseriu os $\S \S 6^{\circ}$ e $7^{\circ}$ no art. 57 da Lei n. $.^{\circ} 8.213 / 91$, e estabeleceu que este benefício será financiado com recursos provenientes da contribuição de que trata o inciso II do art. 22 da Lei $n^{\circ} 8.212 / 91$, cujas alíquotas serão acrescidas de doze, nove ou seis pontos percentuais, conforme a atividade exercida pelo segurado a serviço da empresa permita a concessão de aposentadoria especial após quinze, vinte ou vinte e cinco anos de contribuição, respectivamente.” (...) 12. In casu, tratando-se especificamente do agente nocivo ruído, desde que em limites acima do limite legal, constata-se que, apesar do uso de Equipamento de Proteção Individual (protetor auricular) reduzir a agressividade do ruído a um nível tolerável, até no mesmo patamar da normalidade, a potência do som em tais ambientes causa danos ao organismo que vão muito além daqueles relacionados à perda das funções auditivas. O benefício previsto neste artigo será financiado com os recursos provenientes da contribuição de que trata o inciso II do art. 22 da Lei no 8.212, de 24 de julho de 1991, cujas alíquotas serão acrescidas de doze, nove ou seis pontos percentuais, conforme a atividade exercida pelo segurado a serviço da empresa permita a concessão de aposentadoria especial após quinze, vinte ou vinte e cinco anos de contribuição, respectivamente. $\mathrm{O}$ benefício previsto neste artigo será financiado com os recursos provenientes da contribuição de que trata o inciso II do art. 22 da Lei no 8.212, de 24 de julho de 1991, cujas alíquotas serão acrescidas de doze, nove ou seis pontos percentuais, conforme a atividade exercida pelo segurado a serviço da empresa permita a concessão de aposentadoria especial após quinze, vinte ou vinte e cinco anos de contribuição, respectivamente." (Citação extraída da Ementa ARE 664335/SC,pág. $5)$.

Embora sem mencionar às tutelas de urgência no ARE 664335/SC, a jurisprudência do STF e do STJ fixou a respeito da aposentadoria especial quando houver pedido de tutela de urgência:

RECLAMAÇÃO. CONSTITUCIONAL. PREVIDENCIÁRIO. GUARDA MUNICIPAL. APOSENTADORIA ESPECIAL. ALEGAÇÃO DE OFENSA À TESE VINCULANTE FIXADA POR ESTA CORTE NO AGRAVO EM RECURSO EXTRAORDINÁRIO 1.215.727 - TEMA 1.057 DA REPERCUSSÃO GERAL. 
Artigo: Antecipação dos efeitos da tutela nos processos de aposentadoria especial à luz do princípio da dignidade da pessoa humana

FUMUS BONI IURIS. TUTELA PROVISÓRIA DE URGÊNCIA DEFERIDA. Decisão: Trata-se de reclamação ajuizada pelo Instituto de Previdência do Município de Jacareí/SP contra decisão proferida pelo Juiz Presidente do Colégio Recursal de São José dos Campos/SP nos autos do processo n. 1008191-58.2016.8.26.0292, por suposta afronta à autoridade das decisões proferidas pelo Supremo Tribunal Federal nos Mandados de Injunção 6.515, 6.770, 6.773, 6.780, 6.874 e 6.898, além da decisão proferida no ARE 1.215.727 - Tema 1.057 da repercussão geral. Narra a parte reclamante que é demandada em processo no qual servidor da Prefeitura de Jacareí/SP, guarda municipal, pleiteava a concessão de aposentadoria especial, sob o fundamento de que sua atividade seria de risco. A sentença o acórdão no recurso inominado julgaram procedente a pretensão do servidor, concedendo-lhe a aposentadoria pleiteada, sob o entendimento de que não haveria conflito com o quanto decidido nos mandados de injunção acima mencionados, vez que, no julgamento destes feitos, o Plenário do STF teria se limitado a declarar a impossibilidade de extensão de benefícios, por mora legislativa, "não impedindo que o direito à aposentadoria diferenciada seja reconhecido em situações concretas com base em provas do enquadramento nas hipóteses do art. $40, \S 4^{\circ}$, III, da CF" (doc. 05, fls. 234 e ss.). Argumenta que referida decisão estaria em manifesta afronta à jurisprudência do STF sobre o tema, jurisprudência esta que se assentou no julgamento do ARE 1.215.727 Tema 1.057 da repercussão geral. Requer, liminarmente, a suspensão do processo $\mathrm{n}$. 1008197-58.2016.82.6.0292 e, no mérito, a procedência da reclamação, para reforma da decisão combatida. É o relatório. DECIDO. Ab initio, pontuo que a reclamação, por expressa determinação constitucional, destina-se a preservar a competência desta Suprema Corte e a garantir a autoridade de suas decisões, ex vi do artigo 102, inciso I, alínea 1, além de salvaguardar a estrita observância de preceito constante em enunciado de Súmula Vinculante, nos termos do artigo 103-A, § $3^{\circ}$, ambos da Constituição Federal. No presente caso concreto, sustenta a reclamante a ocorrência de ofensa à tese vinculante fixada por esta Corte no julgamento do Agravo em Recurso Extraordinário 1.215.727, Tema 1.057 da Repercussão Geral, no qual se deu o debate acerca da possibilidade de concessão de aposentadoria especial a guarda civil municipal de acordo com o então inciso II do $\S 4^{\circ}$ do art. 40 da CF, de acordo com a redação anterior à EC 103/2019. Por ocasião daquele julgamento, o Plenário do Supremo Tribunal Federal, em confirmação de jurisprudência anterior, firmou a seguinte tese vinculante: Tema-RG 1.057: "Os guardas civis não possuem direito constitucional à aposentadoria especial por exercício de atividade de risco prevista no artigo 40, $\S 4^{\circ}$, inciso II, da Constituição Federal". Pois bem. O cotejo analítico não exauriente entre a decisão reclamada e o paradigma invocado revela inobservância da autoridade da decisão deste Supremo Tribunal Federal. Com efeito, o juízo reclamado entendeu que guarda municipal teria direito à aposentadoria especial, a despeito de os precedentes vinculante invocados não mencionarem exceção ao entendimento fixado. É o quanto basta, em sede de cognição sumária, para a concessão de tutela provisória de urgência. Ex positis, CONCEDO A TUTELA PROVISÓRIA DE URGÊNCIA, com fundamento no inciso II do artigo 989 do Código de Processo Civil, para suspender os efeitos dos acórdãos proferidos nos autos do processo 100819158.2016.8.26.0292. Solicitem-se informações (artigo 989, inciso I, do CPC) e comunique-se o teor desta decisão ao Juízo reclamado, em especial no que concerne ao deferimento da medida liminar. Cite-se o beneficiário do decisum impugnado para a apresentação de contestação (artigo 989, inciso III, do CPC). Nos termos do artigo 52, parágrafo único, do RISTF, dispenso o parecer da Procuradoria-Geral da República. Publique-se.” (Rcl 39412 MC/SP. Ministro Luiz Fux Relator. Brasília, 10 de março de 2020).

Por esta razão, a tutela antecipada é instrumento hábil e, consequentemente, apto a garantir a efetivação do direito à aposentadoria especial, seja ela concedida em primeiro grau ou em grau recursal e, consequentemente, garantir a efetividade do Princípio da Dignidade da Pessoa Humana, essenciais à sobrevivência do segurado em relação ao caráter alimentar do benefício, bem como sua retirada do ambiente insalubre. 


\section{CONCLUSÃO}

Por tudo o que foi demonstrado na pesquisa, pode-se concluir que o processo jurisdicional exerce um papel fundamental, pois visa garantir que a pretensão do segurado seja efetivada. Como objeto estudado o instituto das tutelas de urgência nos processos de aposentadoria especial, atuam como uma técnica processual para antecipar o mérito, tendo como alvo a urgência, dado que há um desgaste por parte do trabalhador que foi submetido a agentes nocivos à saúde.

Logo, propõe-se dar fim a morosidade do poder judiciário. O tempo de espera do julgamento é maior. Posto que, os Tribunais Regionais Federais abarcam grandes regiões, como é o caso do TRF 1. Em relação a concessão de benefícios previdenciário, tende-se garantir a segurança jurídica e a equidade processual. Portanto, dentre as decisões dos magistrados dos TRF's, verifica-se que há prática reiterada da concessão das tutelas no momento da sentença. Nota-se, que quando há interposição de recursos pelo INSS, ele (recurso) é distribuído apenas com o efeito devolutivo, para que haja a garantia ao segurado que esteja recebendo o benefício e não seja prejudicado. Em razão da natureza alimentar prevista no texto constitucional, as verbas são destinadas ao sustento do trabalhador, dentre eles evidencia-se a proteção aos bens jurídicos. Observa-se que todos os bens jurídicos tutelados estão diretamente ligados à dignidade da pessoa humana.

Como se sabe a aposentadoria especial é uma das sub-espécie de aposentadoria por tempo de contribuição, sua finalidade é considerada especial em razão do exercício de atividade laboral, a fim de amparar o trabalhador que trabalhou em condições nocivas e perigosas a sua saúde, reduzindo o tempo de serviço/contribuição para fins de aposentadoria. No entanto, o novo tratamento dado a aposentadoria especial conforme a EC $\mathrm{n}^{\circ} 103 / 19$, abriu a possibilidade de questionarmos se esse benefício, ainda cumprirá a sua finalidade? Não, motivo pelo qual, é inconstitucional a criação do requisito etário, pois irá obrigar o segurado a permanecer trabalhando em ambiente insalubre por tempo superior ao tempo mínimo quando a implementação do requisito tempo de contribuição de 15, 20 e 25 anos, por outro lado, ainda houve a redução da média salarial de $100 \%$ para $60 \%$. Assim, verifica-se que a EC nº $103 / 19$, viola de vários dispositivos da Constituição, a saber: os artigos $5^{\circ}$, caput; $6^{\circ} ; 7^{\circ}$, XXII; $60, \S 4^{\circ}$, IV; 170; 193, 194, II, IV, V e VI; e 201, $1^{\circ}$ todos da Constituição da República.

Haja vista, a reforma da previdência ter prejudicado o destinatário do benefício de aposentadoria especial, ele não poderá usufruir da conversão de tempo especial em comum, muito menos requerer o benefício mais vantajoso. Tais dispositivos atendiam ao princípio da dignidade da pessoa humana, o devido processo legal e as garantias constitucionais dos trabalhadores. Além disso, permitia ao judiciário julgar de forma ampla, adotando a tese e invocando o princípio da fungibilidade dos benefícios e da hipossuficiência, sendo eles, considerados sob o prisma da razoabilidade.

A propósito a aposentadoria especial assegura contagem diferenciada do tempo trabalhado ao segurado exposto a agentes agressivos, essa distinção se deu pelo fato de que o segurado que trabalha em ambiente salubre tem o seu direito à vida digna e à saúde resguardado.

Levando-se em conta o que foi observado, a tutela de urgência é um instrumento processual capaz a agilizar o processo, tanto no momento da sentença quanto em sede recursal, tornando-o mais justo ao segurado, o qual se encontra em posição desvantagem na relação jurídica. Nesse sentido, a concessão de tal instrumento torna-se eficiente ao ponto de garantir o princípio da dignidade da pessoa humana, o devido processo legal, a celeridade, razoabilidade processual, valorização do trabalho, dentre outros. Por outro lado, observa-se que a entrada em vigor da nova Ec $\mathrm{n}^{\circ} 103 / 19$, prejudicou o segurado de tal forma que poderíamos nos questionarmos, se isso seria a extinção da espécie do benefício de aposentadoria especial. 


\section{REFERÊNCIAS}

BARACHO, José Alfredo de Oliveira. Teoria Geral do Processo Constitucional. Revista Forense. Rio de Janeiro, v. 383, p. 78-169, jan/fev, 2006

BARROSO, Luís Roberto; A Dignidade da Pessoa Humana no Direito Constitucional Contemporâneo: A Construção de um Conceito Jurídico à Luz da Jurisprudência Mundial. Edição. Belo Horizonte: Fórum , 2016. p. 01-132.

BARROSO, Luís Roberto. Curso de Direito Constitucional Contemporâneo. Editora Saraiva, 2009. p. 178-180.

BRASIL. Constituição (1988). Constituição da República Federativa do Brasil. Disponível em: http://www.planalto.gov.br/ccivil_03/constituicao/constituicao.htm. Acesso em: 19 mar. 2020.

BRASIL. Código de Processo Civil. 2015. Disponível em: http://www.planalto.gov.br/ccivil_03/_ato2015-2018/2015/lei/113105.htm. Acesso 20 nov. 2019.

BRASIL. Código de Processo Civil. 1973. Disponível em: http://www.planalto.gov.br/ccivil_03/leis/15869impressao.htm. Acesso 15 fev. 2020.

BRASIL. Conselho de Recursos da Previdência Social-CRPS. Enunciado no 20. Brasília, DOU de 18 de nov. 1999. p. 08. Disponível em:

http://www.mds.gov.br/webarquivos/inss/CRPS/jurisprudencia_administrativa/ENUNCIADO S\%20DO\%20CRSS\%20-\%201\%20A\%2039\%20-\%20PDF.pdf. Acesso em: 10 abr. 2020.

BRASIL. Conselho de Recursos da Previdência Social-CRPS. Enunciado no 21. Brasília, DOU de 18 de nov. 1999. p. 08. Disponível em:

http://www.mds.gov.br/webarquivos/inss/CRPS/jurisprudencia_administrativa/ENUNCIADO S\%20DO\%20CRSS\%20-\%201\%20A\%2039\%20-\%20PDF.pdf. Acesso em: 10 abr. 2020.

BRASIL. Emenda Constitucional no 103. Diário Oficial da República Federativa do Brasil, Poder Executivo, Brasília, DF. Disponível em:

http://www.planalto.gov.br/ccivil_03/constituicao/emendas/emc/emc103.htm. Acesso em: 13 abr. 2020.

BRASIL. Decreto $n^{0}$ 2.172, anexo IV, de 05 de março de 1997. Dispõe sobre a classificação dos agentes nocivos. Brasília, DF: Presidência da República: Disponível em:

http://qualidade.ieprev.com.br/UserFiles/File/Anexo\%20IV\%20do\%20Decreto\%202_172-

1997.pdf. Acesso em: 10 mar. 2020.

BRASIL. Decreto no 3.048, de 06 de maio de 1999. Aprova o Regulamento da Previdência Social, e dá outras providências. Brasília, DF: Presidência da República: Disponível em: http://www.planalto.gov.br/ccivil_03/decreto/d3048.htm. Acesso em: 05 mar. 2020.

BRASIL. Decreto no 3.048, de 06 de maio de 1999. Aprova o Regulamento da Previdência Social, e dá outras providências. Brasília, DF: Presidência da República: Disponível em: http://www.planalto.gov.br/ccivil_03/decreto/d3048.htm. Acesso em: 05 mar. 2020. 
BRASIL. Decreto n. 4.882 de 18 de novembro de 2003. Altera dispositivos do Regulamento da Previdência Social, aprovado pelo Decreto n ${ }^{\circ} 3.048$, de 6 de maio de 1999. Brasília, DF: Presidência da República. Disponível em:

http://www.planalto.gov.br/ccivil_03/decreto/2003/D4882.htm. Acesso em: 11 mar. 2020.

BRASIL. Decreto n. 4.827 de 03 de setembro de 2003. Altera o art. 70 do Regulamento da Previdência Social, aprovado pelo Decreto no 3.048, de 6 de maio de 1999. Brasília, DF: Presidência da República. Disponível em:

http://www.planalto.gov.br/ccivil_03/decreto/2003/D4827.htm. Acesso em: 11 mar. 2020.

BRASIL. Decreto-lei no 1.608, de 18 de setembro de 1939. Dispõe sobre o Código de Processo Civil. O PRESIDENTE DA REPÚBLICA usando da atribuição que lhe confere o artigo 180 da Constituição, decreta a seguinte lei: Disponível em:

http://www.planalto.gov.br/ccivil_03/Decreto-Lei/1937-1946/Del1608.htm. Acesso em: 23 mar. 2020.

BRASIL. Decreto-lei no 3.807, de 26 de agosto de 1960. Dispõe Sobre a Lei Orgânica da Previdência Social: Disponível em: http://www.planalto.gov.br/ccivil_03/leis/19501969/13807.htm. Acesso em: 20 mar. 2020.

BRASIL. Decreto-lei no 53.831, de 25 de março de 1964. Dispõe sobre a aposentadoria especial instituída pela Lei 3.807, de 26 de agôsto de 1960.: Disponível em: http://www.planalto.gov.br/ccivil_03/decreto/D53831.htm. Acesso em: 15 mar. 2020.

BRASIL. Decreto no 83.080, de 24 de janeiro de 1979. Aprova o Regulamento dos Benefícios da Previdência Social.. Brasília, DF: Presidência da República: Disponível em: http://www.planalto.gov.br/ccivil_03/decreto/D83080.htm. Acesso em: 10 mar. 2020.

BRASIL. Instrução Normativa $\mathbf{n}^{\mathbf{0}} 77$ de 21 de janeiro de 2015. Estabelece rotinas para agilizar e uniformizar o reconhecimento de direitos dos segurado se beneficiários da Previdência Social,com observância dos princípios estabelecidos no art. 37 da Constituição Federal de 1988. Ministério da Previdência Social/ Instituto Nacional do Seguro Social. Brasília em 21 de janeiro de 2015.Edição, 15. Seção, 1. Pág. 32.

BRASIL. Lei 8.212/1991. Disponível em: Acesso em:

http://www.planalto.gov.br/ccivil_03/Leis/L8212cons.htm. 19 mar. 2020.

BRASIL. Lei 8.213/1991. Disponível em: Acesso em: http://www.planalto.gov.br/ccivil_03/leis/18213cons.htm. 20 nov. 2019.

BRASIL. Lei 8.952/1994. Disponível em: Acesso em: http://www.planalto.gov.br/ccivil_03/LEIS/L8952.htm. 01 mai. 2020.

BRASIL. Lei 9.032/1995. Disponível em: Acesso em: http://www.planalto.gov.br/ccivil_03/leis/L9032.htm. 01 mai. 2020.

BRASIL. Lei 9.528/1997. Disponível em: Acesso em: http://www.planalto.gov.br/ccivil_03/LEIS/L9528.htm. 17 abr. 2020. 
Artigo: Antecipação dos efeitos da tutela nos processos de aposentadoria especial à luz do princípio da dignidade da pessoa humana

BRASIL. Lei 9.711/1998. Disponível em: Acesso em:

http://www.planalto.gov.br/ccivil_03/leis/L9711.htm 11 abr. 2020.

BRASIL. Ministério do Trabalho e Emprego. NR 06 - Equipamento de Proteção Individual EPI. Brasília: Ministério do Trabalho e Emprego, 2001. Disponível em:

http://trabalho.gov.br/images/Documentos/SST/NR/nr-06-atualizada-2018.pdf. Acesso em: 10 abr. 2020.

BRASIL. Superior Tribunal de Justiça (1. Turma). Recurso Especial 1.495.146-MG. Aplicação do art. $1^{\circ}$-F da Lei n. 9.494/1997 (com redação dada pela Lei n. 11.960/2009). Condenações impostas à Fazenda Pública. Correção monetária. Impossibilidade de fixação apriorística. Recorrente: Instituto de Previdência dos Servidores Militares de Minas Gerais Ipsm . Recorrido:Alair Rosa da Silva Recorrido, Valde Ferreira Venuto Recorrido, Antonio Carlos Silva Cruz . Relator: Min. Mauro Campbell Marques, 22 de fevereiro de 2018. Lex: jurisprudência do Superior Tribunal de Justiça, Brasília, DJe 02/03/2018.

BRASIL. Supremo Tribunal Federal, Plenário. RECURSO EXTRAORDINÁRIO COM AGRAVO N ${ }^{\circ}$ 664.335. Antonio Fagundes vs. Instituto Nacional do Seguro Social - INSS. Santa Catarina.04/12/2014. Disponível em:

http://redir.stf.jus.br/paginadorpub/paginador.jsp?docTP=TP\&docID=7734901.pdf. Acesso em: 20 nov. 2019.

BRASIL. Superior Tribunal Justiça. Súmula $\mathbf{n}^{\circ} 7$ - A pretensão de simples reexame de prova não enseja recurso especial - Órgão Julgador: CE - CORTE ESPECIAL - Data do Julgamento: 28/06/1990 - Data da Publicação/Fonte: DJ 03/07/1990 p. 6478 - RSTJ vol. 16 p. 157 - RT vol. 661 p. 172.Disponível em:

http://www.stj.jus.br/docs_internet/VerbetesSTJ_asc.pdf. Acesso em: 11 abr. 2020.

BRASIL. Supremo Tribunal Federal (1. Turma). Agravo Regimental no Agravo de Instrumento 829.651-MG. A jurisprudência desta Corte firmou-se no sentido de que o benefício previdenciário recebido de boa-fé pelo segurado em virtude de decisão judicial não está sujeito à repetição de indébito, dado o seu caráter alimentar [...]. Agravante: Instituto Nacional De Seguro Social - INSS. Agravado: Zuleik Barbosa de Oliveira. Relatora: Min. Rosa Weber, 08 de março de 2013. Diário de Justiça Eletrônico, Brasília, DF. Disponível em: http://redir.stf.jus.br/paginadorpub/paginador.jsp?docTP=TP\&docID=4418440. Acesso em: 23 mar. 2020.

BRASIL. Tribunal Superior do Trabalho. Súmula no 289 - O simples fornecimento do aparelho de proteção pelo empregador não o exime do pagamento do adicional de insalubridade, cabendo-lhe tomar as medidas que conduzam à diminuição ou eliminação da nocividade, dentre as quais as relativas ao uso efetivo do equipamento pelo empregadoÓrgão Julgador: Min. Marco Aurélio Mendes de Farias Mello Res. 121/2003- Data do Julgamento: 21.11.2003 - Data da Publicação/Fonte: DJ 13 de nov. 2003 p. 19-20.Disponível em:

http://www3.tst.jus.br/jurisprudencia/Sumulas_com_indice/Sumulas_Ind_251_300.html\#SU M-289. Acesso em: 13 abr. 2020

BRASIL. Turma Nacional de Uniformização Dos Juizados Especiais Federais. Súmula $\mathbf{n}^{\circ} \mathbf{6 8}$. O laudo pericial não contemporâneo ao período trabalhado é apto à comprovação da atividade especial do segurado. Brasília, DF: Superior Tribunal de Justiça, [2007]. Disponível em: 
https://www.cjf.jus.br/phpdoc/virtus/sumula.php?nsul=68\&PHPSESSID=3go9li2s89jlaiuft6a 2tav390. Acesso em: 05 abr. 2020.

CASTRO, C. A. P. D; LAZZARI, João Batista; Manual de Direito previdenciário: De Acordo com a Reforma Previdenciária EC. 103 de 12.11.2019. 23. ed. Rio de Janeiro: forense, 2020. p. 01-2398. [PDF].

CONJUR. A norma mais chocante da nova reforma da Previdência. Disponível em: https://www.conjur.com.br/2019-nov-14/interesse-publico-norma-chocante-reformaprevidencia. Acesso em: 18 mai. 2020.

CUNHA, Leonardo Carneiro da. A fazenda Pública em juízo. $13^{\mathrm{a}}$ ed. totalmente reformulada. Rio de Janeiro: Forense, 2016, p.306.[PDF].

DINAMARCO, Cândido Rangel; O Regime Jurídico das medidas Urgentes: A Nova Era do Processo Civil . Edição. São Paulo: Malheiro, 2003. p. 36.

DIZER O DIREITO. Índices de juros e correção monetária aplicados para condenações contra a Fazenda Pública. Disponível em:

https://www.dizerodireito.com.br/2018/04/indices-de-juros-e-correcao-monetaria.html. Acesso em: 22 jul. 2019.

FRANZÉ, Luís Henrique Barbante; CALIL, Mário Lúcio Garcez; FRANÇOSO, Larissa Fatima Russo. A Proteção Processual do Segurado: A Tutela Antecipada Recursal na Aposentadoria Especial. Revista da Faculdade de Direito do Sul de Minas, Pouso Alegre, ano 2019, v. 35, ed. 1, p. 47-57, 24 abr. 2018. Disponível em:

https://www.fdsm.edu.br/conteudo/artigos/50099ee0f5939fc53a26ae2e5ac43dac.pdf. Acesso em: 20 nov. 2019.

FERNANDES, Bernardo Gonçalves; Curso de Direito Constitucional.9. ed. rev. ampl. Jus Podivm. Salvador, 2017. p. 622 - 642. [PDF].

FUGA, Bruno Augusto Sampaio et al. Principais inovações do Novo código de Processo Civil. 2. ed. Londrina/PR: Editora Thoth, 2019. Disponível em:

https://books.google.com.br/books?id=vOCGDwAAQBAJ\&pg=PA244\&lpg=PA244\&dq=Oc orre,+contudo, + que + a+tutela+antecipada+\%E2\% $80 \% 93+$ fundada+na+urg $\%$ C3\%AAncia+ou +na+evid\%C3\%AAncia+\% E2\%80\%93+\%C3\%A9+satisfativa,+isto+\%C3\%A9,+produz+tota 1+ou+parcialmente+a+efic\% C3\%A1cia+material+desejada+pelo+autor,\&source=bl\&ots=VF AUxnGte0\&sig=ACfU3U3Bbwxv9wtGKp212R1POCZiZiCrQQ\&hl=pt-

BR\&sa=X\&ved=2ahUKEwjo04veyYPmAhXyx1kKHdgxCJsQ6AEwCnoECA0QAQ\#v=one page \&q\&f=false. Acesso em: 18 nov. 2019.

IBRAHIM, Fábio Zambite. Curso de direito previdenciário. 12. ed. Niterói: Impetus, 2008. p. 552. [PDF].

JUNIOR, Humberto Theodoro. Curso de Direito Processual Civil: Teoria Geral do Direito Processual Civil, Processo de conhecimento e procedimento comum. Vol. I.58 ed. Rio de Janeiro: Forense, 2017. p. 3-1257. 
MANCINI, Jorge Rodríguez. Derechos Fundamentales y Relaciones Laborales. Buenos Aires: Editorial Astrea, 2004.

MARINONI, Luiz Guilherme. Tutela de Urgência e Tutela de Evidência [livro

Eletrônico]. $1^{a}$ ed. São Paulo: Revista dos Tribunais, 2017. [PDF].

MARINONI, Luiz Guilherme. Antecipação da tutela. $9^{\text {a }}$ Ed atualizada e ampliada. São Paulo: RT, 2006. p.525. [PDF].

MENDES, Gilmar Ferreira; BRANCO, Paulo Gonet. Curso de Direito Constitucional. 15 ed. São Paulo, 2020. p.01 - 2412. [PDF].

MENDES, Gilmar Ferreira; COELHO, Inocêncio Mártires; BRANCO, P. G. G; Curso de Direito Constitucional. 4. ed. São Paulo: Saraiva, 2009. [PDF].

MINAS GERAIS. Tribunal Regional Federal 1. Processo: AC 2008.01.99.039906-3. Relator: Desembargador Federal Antônio Sávio de Oliveira Chaves. p. 278. Belo Horizonte, 26 fev. 2009. Disponível em:

https://edj.trf1.jus.br/edj/bitstream/handle/123/17849/Cadernos_JUD_TRF_2019-05-

08_XI_82.pdf?sequence=1\&isAllowed=y. Acesso em: 19 mar. 2020.

MORAES, Alexandre de. Direito Constitucional. 36 ed. rev. atua. ampl. São Paulo: Atlas, 2020. p. 374-396. [PDF].

OLIVEIRA, Marcelo Andrade Cattoni de. Processo Constitucional, 3. ed. rev. e ampl. Belo Horizonte: Fórum, 2016. 350p.

PEREIRA, Denisson Almeida. Aposentadoria Especial: Discutindo a sua finalidade e conceito. Informe de Previdência Social, Brasília, v. 23, n. 2, p. 01-28, dez./2005. Disponível $\mathrm{em}$ : http://sa.previdencia.gov.br/site/arquivos/office/3_110222-165450-129.pdf. Acesso em: 5 mai. 2020.

\section{SABER A LEI. Regras de Transição da Aposentadoria Especial Após Reforma da}

Previdência. Disponível em: https://saberalei.com.br/regras-de-transicao-aposentadoriaespecial/. Acesso em: 18 mai. 2020.

SANTA CATARINA. Tribunal Regional Federal 4. Processo: AC 275145 SC 2005.0275145. Relator: Francisco Donizete Gomes. Florianópolis, 23 jul. 2015. Disponível em: https://www2.trf4.jus.br/trf4/controlador.php?acao=consulta_processual_resultado_pesquisa\& $\underline{\text { txtValor }=50147975020154047200 \& \text { selOrigem }=S C \& \text { chkMostrarBaixados }=\& \text { selForma }=\text { NU\& }}$ hdnRefId=8e913c6d1628d36ff5020e4d245469a1\&txtPalavraGerada=godR. Acesso em: 19 dez. 2018.

SARLET, Ingo Wolfgang. MARINONI, Luiz Guilherme. MITIDIERO, Daniel; Curso de Direito Constitucional. 6. ed. São Paulo: Saraiva, 2017. p. 278-1668.[PDF]

STJ. Aposentadoria especial pode ter laudo técnico dispensado quando instruída com perfil profissiográfico. Disponível em:http://www.stj.jus.br/sites/portalp/Paginas/Comunicacao/Noticias-antigas/2017/2017-02- 
14_08-06_Aposentadoria-especial-pode-ter-laudo-tecnico-dispensado-quando-instruida-comperfil-profissiografico.aspx. Acesso em: 2 abr. 2020.

TAVARES, André Ramos. Curso de Direito Constitucional. 18 ed. São Paulo. Saraiva Educação, 2020, p. 01- 1945. [PDF].

ZANINI, Juliano Cesar. O direito fundamental aos benefícios previdenciários e a impossibilidade de aplicação do prazo decadencial na revisão dos atos de concessão: inconstitucionalidade do art. 103, caput, da lei n. 8.213/911. Revista da Academia Brasileira de Direito Constitucional: Constituição, Economia e Desenvolvimento, Curitiba, v. 5, n. 8, p. 119-155, dez./2005. Disponível em:

http://www.abdconst.com.br/revista9/direitoJuliano.pdf. Acesso em: 25 mar. 2020. 